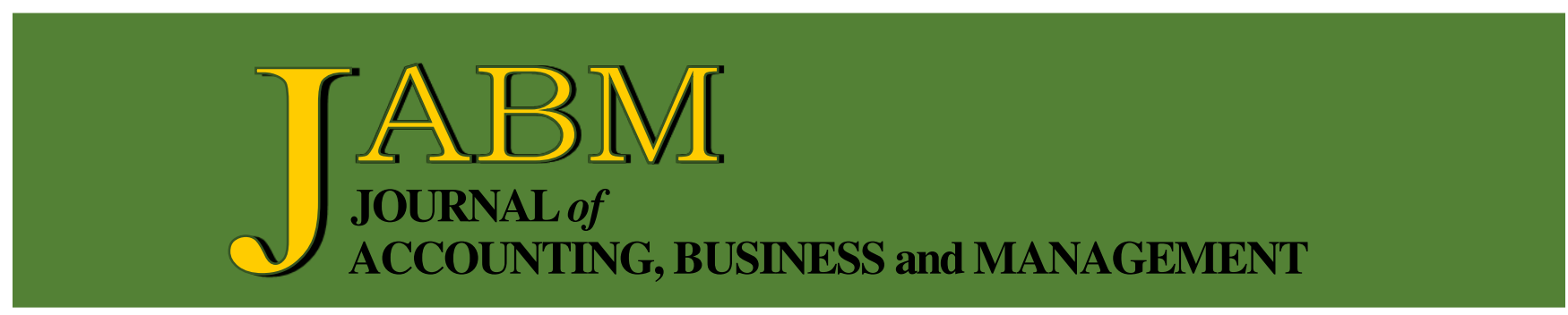

Life Insurance Companies: Determinants of Cost Efficiency and Profitability

Joseph Kwadwo Tuffour, Kenneth Ofori-Boateng, Williams Ohemeng, and Jane Kabukuor Akuaku

Subprime Crisis - A Corporate Acquisition Opportunity?

Vishal Srivastava, Sunder Ram Korivi, and Dipasha Sharma

Consequences of Weak Internal Controls Over Financial Reporting: Foreign versus U.S. Firms

Kathleen Bakarich and Devon Baranek

Impact of Organizational Commitment on Accounting Professionals' Performance: Case of Accounting Firms

Lassaad Abdelmoula and Sami Boudabbous

The Objectives of Sharia Management Accounting Information Reporting: Identification of Values and Characteristics

Sonhaji, Abdul Kadir Usri, and Hedher Tuakia

The Impact of Customer's Perception of the Practices of Corporate Social Responsibility on Purchase Intention

Doaa Abd El Samea and Ahmed Rashed

Corporate Financial Distress: The Impact of Profitability, Liquidity, Asset Productivity, Activity and Solvency

Karikari Amoa-Gyarteng

Determinant Factors of Social Cohesion and Inclusion of Street Vendors in Jakarta: Key Factor Surviving During Covid-19 Pandemic

Beti Nurbaiti 
Journal of Accounting, Business and Management (JABM) vol. 28 no. 2 (2021) 34-58

\title{
Consequences of Weak Internal Controls Over Financial Reporting: Foreign versus U.S. Firms
}

\author{
Kathleen Bakarich* \\ Devon Baranek†
}

\begin{abstract}
For a sample of both foreign cross-listed firms and U.S. firms that report material weaknesses in internal control over financial reporting (MWICFR) from 20072016, we utilize event studies and multivariate techniques to examine if there are differential consequences of reporting MWICFR across the two groups. Specifically, we examine the reactions of the equity and debt markets, external auditors, and the firm's governance. We find that after receiving an audit report with material weakness issues, foreign firms face a significantly more negative stock market reaction and decrease in credit ratings. These firms are more likely to receive a going-concern audit opinion than U.S. firms and are also significantly less likely to change their CEOs or CFOs. Additionally, we find that the strength of the home market regulatory environment mitigates the negative equity and debt market reactions for foreign firms. Lastly, we also find that the presence of foreign auditors for foreign firms alleviates audit market consequences, resulting in a lower likelihood of auditor resignations and going-concern audit opinions. This paper extends and complements the existing literature on cross-listed firms by documenting differences in the consequences for firms reporting weaknesses in ICFR and exploring the traits driving these differences.
\end{abstract}

Keywords: material weakness, internal controls over financial reporting, cross-listed firms, consequences.

\section{INTRODUCTION}

The U.S. capital markets have long been a preferred destination for foreign companies looking to establish a trading presence, with these firms realizing a number of benefits, including increased visibility and access to less costly capital and improved credibility (Reese \& Weisbach, 2002; Doidge et al., 2004; and Karolyi, 2006). Because of these advantages, the number of foreign issuers cross-listing on U.S. exchanges has seen continued growth over the past decade. ${ }^{1}$ These cross-listed firms are not exempt from the onerous reporting requirements mandated by the securities and exchange commission (SEC), including those pertaining to the evaluation and certification of internal controls over financial reporting by management and auditors. The U.S. was the first country to mandate formal disclosure on internal control over financial reporting

\footnotetext{
* Corresponding author. Assistant professor, Department of Accounting, Taxation \& Legal Studies in Business, Zarb School of Business, Hofstra University, Hempstead, NY 11549. Phone: +1-516-463-6993. E-mail: kathleen.bakarich@hofstra.edu.

† Assistant professor, Department of Accounting, Brodsky School of Business, Rider University, Lawrenceville, NJ 08648. Phone: +1-609-895-5520. E-mail: dbaranek@rider.edu.

${ }^{1}$ Since the 2008 financial crisis, while the total number of listed domestic companies has remained relatively steady, foreign companies listed on U.S. exchanges have steadily increased in number and more foreign companies select the U.S. to cross-list versus any other world market (EY, 2017).
} 
(ICFR) with the passage of the Sarbanes-Oxley act (SOX), one of several regulatory reforms intended to raise the level of public trust in financial reporting.

Prior research in the area of ICFR and cross-listed firms has focused on the determinants of material weaknesses, finding that foreign firms are more likely to report material weaknesses than U.S. firms, and that this likelihood is impacted by accounting standards, rule of law, internal control guidance, and culture (Kanagaretnam et al., 2016; Wilford, 2016; and Caban-Garcia et al., 2017). We extend this existing research by selecting a subsample of U.S. and foreign cross-listed companies whose auditors have already disclosed a material weakness in internal control over financial reporting (MWICFR) and investigate the aftereffects of this disclosure. We examine whether foreign firms reporting deficiencies face the same consequences as their U.S. counterparts from three distinct perspectives: 1) equity and debt market investors, 2) external auditors, and 3) the firms themselves.

While the consequences of MWICFR for U.S. firms has been studied, the potential varying impact for foreign cross-listed firms compared to U.S. firms has been left relatively unexamined. However, given prior research that these foreign firms differ from their U.S. peers in terms of earnings quality (Lang et al., 2006), reporting of material weaknesses (Wilford, 2016), and restatement rates (Srinivasan et al., 2015), there exists the possibility that the aftereffects of reporting internal control issues may also differ. Prior literature has found the consequences for U.S. firms reporting material weaknesses include our three areas of interest: negative stock market reactions and increased cost of debt capital (equity and debt market investors); higher audit fees, higher auditor dismissal and resignation rates, and higher going-concern opinion rates (external auditors); and higher turnover of boards of director members, audit committees, and top management (the firms themselves) (Raghunandan \& Rama, 2006; Ogneva et al., 2007; Hammersley et al., 2008; Hogan \& Wilkins, 2008; Hoitash et al., 2008; Ashbaugh-Skaife et al., 2009; Ettredge et al., 2011; and Johnstone et al., 2011). Thus, while consequences exist, whether they are different for foreign crosslisted firms remains an empirical question.

It is also possible that other factors may mitigate the impact of reporting a material weakness for foreign firms. Prior literature has found that cross-listing effects, such as cost of capital, changes in earnings quality, and valuation premiums, are impacted by the strength of legal institutions in the foreign firm's home market (e.g. Doidge et al., 2004; Lang et al., 2006; and Hail \& Leuz, 2009). Additionally, Wilford (2016) finds that foreign firms from strong rule of law countries are less likely to report material weaknesses than those from weak rule of law countries, indicating the importance of taking this factor into consideration when examining internal control issues. Thus, we consider whether the regulatory quality of the home market exacerbates or mitigates any potential aftereffects of MWICFR.

In addition to the importance of the home market's institutions, an equally important role is played by the audit firm issuing the internal control audit report. While most ICFR studies include a control for the size of the audit firm, as a proxy for audit quality, we also incorporate the location of the audit firm as a potential factor that may influence the consequences of reporting a material weakness in this international study. Asthana et al. (2015) find that cross-listed firms with U.S.based Big $\mathrm{N}$ auditors have higher audit quality, and higher fees, than when the principal auditor is foreign-based and that investors value firms' earnings more highly when the auditor is U.S.-based rather than home country-based. Reports by the international forum of independent audit regulators (IFIAR) highlight differences in inspection 
results among audit firms in different countries reflecting varying degrees of audit quality, even within the same firm, globally (Ferguson, 2015). The impact of foreign auditors in cross-listing is currently an unexplored area of research, but given the discussions of the potential variation in audit quality from prior research and its influence on investors' perceptions, we also consider whether the location, foreign or U.S., of the audit firm exacerbates or mitigates any possible consequences of MWICFR.

Examining 141 foreign cross-listed and 1,014 U.S. firm-year observations with material weaknesses from 2007-2016, we find that, after reporting material weakness issues in the auditor's report, foreign firms face a significantly more negative stock market reaction, a significant decrease in credit ratings, are significantly less likely to change their $\mathrm{CEOs}$ or $\mathrm{CFOs}$, and are significantly more like to receive a going-concern audit opinion than U.S. firms. The results show that both the equity and debt markets react more negatively to foreign firms with MWICFR than U.S. firms, indicating that investors and creditors view material weakness issues for foreign firms as more problematic and signals of lower quality compared to U.S. firms. This is further confirmed by the higher likelihood of receiving a going-concern audit opinion for foreign firms. Additionally, foreign firms' lower likelihood to initiate change in top management reflect the possibility of lower corporate governance quality. As it relates to changes in audit fees and auditor resignations, the results are not statistically significant, implying overall, auditors do not appear to treat foreign firms differently from U.S. firms when MWICFR are disclosed.

Further scrutinizing these variations, we find that the home market regulatory environment mitigates the negative equity and debt market reactions for foreign firms. We also find that the presence of foreign auditors for foreign firms does impact audit market consequences, resulting in a lower likelihood of auditor resignations and going-concern audit opinions. These results could reflect low audit quality of foreign as compared to U.S.-based auditors (Asthana et al., 2015) or a lower liability exposure for foreign auditors compared to the U.S. audit environment (Seetharaman et al., 2002; Cheng et al., 2014). Lastly, neither home market legal institutions nor the location of the auditor impacts the turnover of the $\mathrm{CEO}$ or $\mathrm{CFO}$, thus, the negative relation between foreign firms and change in top management is not mitigated by any additional factors and appears to be a firm-level decision.

This study provides a timely analysis of whether ICFR reporting impacts firms' operating and reporting environments. Following passage of the Dodd Frank wall street eeform and consumer protection act in September 2010, non-accelerated filers ${ }^{2}$, both foreign and U.S., are exempt from including an auditor's report on the effectiveness of ICFR, that is complying with SOX section 404. However, the government accountability office's 2013 report on internal control found that compliance with the auditor attestation of internal controls has a positive impact on investor confidence and this independent scrutiny is an important safeguard. ${ }^{3}$ Thus, by examining the consequences of firms whose auditors report a MWICFR we contribute to the debate about whether these types of audit reports still matter.

\footnotetext{
${ }^{2}$ Per the SEC, a non-accelerated filer is a reporting company that does not meet the definition of either an "accelerated filer" (market value between $\$ 75$ million to $\$ 700$ million) or a "large accelerated filer" (market value of $\$ 700$ million or more) under exchange act rule 12b-2 (SEC, 2010).

${ }^{3}$ https://www.gao.gov/assets/660/655710.pdf.
} 
Given that cross-listed firms represent an important segment of the U.S. equity market, understanding the ramifications of reporting material weaknesses in internal controls over financial reporting for this subset of firms compared to U.S. firms is important for regulators, auditors, capital market and organizational stakeholders, and investors. Prior research suggests disparities exist in the quality and transparency of financial reporting disclosures between domestic and foreign firms (Lang et al., 2003; Lang et al., 2006; and Hope et al., 2013). We extend and complement the existing literature on cross-listed firms by documenting differences in the consequences for firms reporting weaknesses in ICFR and what traits drive those differences. To the best of our knowledge, this is the first study to explicitly examine the consequences of MWICFR for this subset of firms. Thus, we add not only to the literature on MWICFR for foreign firms (Wilford, 2016; Caban-Garcia et al., 2017), but also to the general literature on the consequences of MWICFR (Raghunandan \& Rama, 2006; Beneish et al., 2008; Hammersley et al., 2008; Hoitash et al., 2008; Ettredge et al., 2011; and Hammersley et al., 2012).

The rest of the study is organized as follows. The next section provides background information, a literature review, and the research questions. The sample selection and research design are discussed in section 3. The main results are examined in section 4 and section 5 concludes the paper

\section{LITERATURE REVIEW}

\subsection{Cross-Listing Institutional Background}

The passage of Sarbanes-Oxley (SOX) in 2002 expanded and formalized the legislation relating to the certification and reporting of ICFR. In particular, two sections of SOX focus on ICFR: sections 302 and 404. Section 302 requires managers to certify and assert that all SEC disclosures are truthful and reliable, and that management has taken any necessary steps to ensure the internal processes and controls of the company are capable of producing reliable financial information (SEC, 2002; 2003). Any material weaknesses detected must be disclosed, and management is then required to conclude ICFR was ineffective. Section 404 requires firms to have an external auditor report on the reliability of management's assessment of internal controls (SEC, 2003). This legislation aims to improve the quality, reliability and transparency of financial reporting by requiring companies to maintain effective ICFR through annual assessment, attestation and disclosure.

Foreign firms cross-listing in the U.S. are not exempt from these financial reporting requirements and must comply with all applicable sections of SOX, which are often stricter and more comprehensive than a firm's home country. Cross-listed firms face increased costs, additional reporting, disclosure and compliance requirements, extra listing fees, fines and potential shareholder lawsuits, and higher levels of public scrutiny (Seetharaman et al., 2002; Li, 2014).

Despite the increased oversight and disclosure requirements mandated by SOX, there are numerous advantages of cross-listing for foreign firms, including reducing the cost of capital, increasing market liquidity, improving information disclosures, increasing investor protections, and increasing firm visibility (Lang et al., 2003; Doidge et al., 2004; and Hail \& Leuz, 2009). Other benefits include increased valuations (Doidge et al., 2004) and improved access to equity markets (Reese \& Weisbach, 2002). The ongoing filing requirements, rigorous oversight, and increased prominence for these companies has been shown to improve the credibility and reporting quality of financial disclosures for cross-listed firms (Karolyi, 2006). 
There is a contrasting stream of research showing the quality of financial reporting disclosures by cross-listed firms to be lower than that of U.S. firms. Lang et al. (2006) find more evidence of earnings management for foreign firms, as well as greater variations in accounting quality based on levels of home country investor protection and legal enforcement. Leuz et al. (2003) examine the link between corporate governance and the quality of reported earnings and find more pervasive earnings management in countries with fewer investor protections in place. Atilgan et al. (2015) find that information asymmetry is higher for cross-listed firms than U.S. firms when issuing bonds, resulting in more conservative ratings and less frequent upgrades.

Previous studies suggest that despite the stringent rules required to list on a U.S. exchange, there are differences in the disclosure quality between cross-listed and domestic firms. Cross-listed firms from countries with weak investor protections are less likely to provide management forecasts (Hope et al., 2013), less likely to restate their financial statements (Srinivasan et al., 2015) and less likely to voluntarily disclose internal control deficiencies (Gong et al., 2013) than firms from strong rule of law countries. Wilford (2016) examines differences between MWICFR reporting in foreign and U.S. and finds evidence that internal control reporting differs between foreign firms and U.S. companies, with foreign firms from strong rule of law countries (and those that prepare financial statements using IFRS) less likely to report material weaknesses. Caban-Garcia et al. (2017) show foreign firms from home countries providing ICFR guidance are less likely to report material weaknesses. Thus, evidence exists that MWICFR reporting varies across U.S. and foreign firms, and within foreign firms.

Other studies have examined more informal factors, such as culture, and its influence on ICFR. Kanagaretnam et al. (2016) find an association between several dimensions of national culture (individualism, uncertainty avoidance and power distance) and the existence of material weaknesses in internal control, as well as the propensity to remediate a previously detected material weakness. Caban-Garcia et al. (2017) find that firms from countries with a high-power distance and long-term orientation are more likely to report MWICFR.

\subsection{Material Weaknesses in ICFR}

This paper focuses on the aftereffects for foreign and U.S. firms receiving audit reports with material weaknesses in internal control from three different viewpoints: 1) equity and debt market investors, 2) external auditors, and 3) the firms themselves. We therefore provide a brief overview of the ICFR literature in each of these areas. Despite the widespread adoption of ICFR mandates and legislation, the majority of empirical evidence on consequences of MWICFR is centered in the U.S.

\subsubsection{Investors}

Previous empirical evidence suggests effective systems of internal control contribute to high-quality financial reports (Altamuro \& Beatty, 2010), while firms with ineffective ICFR generate less reliable financial information for investors (Doyle et al., 2007a; Ashbaugh-Skaife et al., 2008; and Feng et al., 2009). Prior research examining the determinants of material weaknesses in ICFR find these firms are typically less profitable, smaller in size, more complex, and experience more restructuring (Ge \& McVay, 2005; Doyle et al., 2007b). Studies examining the consequences of reporting ineffective ICFR find these firms are associated with lower levels of financial reporting accruals quality and accounting conservatism, as well as weak internal controls (Doyle 
et al., 2007a; Asbaugh-Skaife et al., 2008; and Goh \& Li, 2011). Outside of the U.S., Brown et al. (2014) investigate the effects of internal control reform in Germany on accounting quality and find that after the reform German firms exhibit more timely loss recognition and lower levels of earnings smoothing, as well as a decrease in loss avoidance behavior. These results support the notion that internal control reforms may improve earnings quality and have positive consequences for other capital markets besides the U.S.

As it relates to market reactions, Hammersley et al. (2008) and Beneish et al. (2008) find the existence of material weaknesses in ICFR under SOX 302 is associated with negative stock market reactions. Beneish et al. (2008) further study SOX 404 disclosures and find no significant market reaction. Ashbaugh-Skaife et al. (2009) find that firms with internal control deficiencies have significantly higher idiosyncratic risk, systematic risk and cost of equity. Studying the debt markets' reaction, Hammersley et al. (2012) find firms with more pervasive material weakness issues experience increases in credit ratings (indicating lower credit quality) and increases in the cost of debt capital.

\subsubsection{Auditors}

Prior studies show firms reporting material weaknesses in internal control under sections 302 and 404 of SOX pay higher audit fees. Raghunandan and Rama (2006) examine audit fees after section 404 disclosures became mandatory and find audit fees to be significantly higher for firms disclosing a material weakness. They also find evidence that the association does not vary depending on the nature of the material weakness (systemic versus non-systemic).

Hoitash et al. (2008) examine audit fees during the initial periods of SOX implementation for firms disclosing internal control problems. They find audit pricing to vary by ICFR problem severity, and that firms disclosing internal control problems continue to pay higher audit fees in subsequent years, even if no additional issues are disclosed. Hogan and Wilkins (2008) show firms with ICFR deficiencies have significantly higher audit fees in the fiscal year preceding the year of the deficiency disclosure and that audit fees increase in severity with the underlying internal control issue, suggesting that audit firms increase their time and effort when control risks increase.

Companies receiving adverse ICFR opinions are more likely to subsequently dismiss their auditors (Ettredge et al., 2011). These auditor changes are more likely to reflect a switch to higher quality auditors and those selecting industry specialists are more likely to improve their ICFR. Hammersley et al. (2012) find that firms that fail to remediate their ICFR issues are more likely to receive modified and going-concern audit opinions. Additionally, they find that the number of material weaknesses is positively associated with auditor resignations.

Lawrence et al. (2018) examine whether operational control risk indicators can be used as signals to potential undetected material weaknesses in ICFR. They document a positive association between operational control risk indicators and future financial reporting control weaknesses, restatements, SEC comment letters and audit fees. Firms with high operational risk are 1.55 times more likely to report material weaknesses in ICFR and pay higher audit fees, suggesting that assessments of operating controls may help auditors in their assessment of company-wide control strength.

Existing literature supports that U.S.-based and foreign auditors provide varying levels of audit quality. Asthana et al. (2015) find Big N auditors improve the financial reporting environment by reporting higher-quality audited earnings for their U.S. listed 
foreign clients. Annual inspection reports from the global public policy committee working group of the international forum of independent audit regulators (IFIAR) provide anecdotal evidence of differences in the quality of audits performed in different countries (Ferguson, 2015). Audits of ICFR are now an integral part of the overall audit process, making it likely that differences exist in the audit quality provided by foreign versus domestic auditors in this area as well.

\subsubsection{Firm management}

Several studies indicate the attitude of key personnel may partially explain variations observed in firms' reporting practices and strategic outcomes (Bamber et al., 2010; Dyreng et al., 2010). A weak "tone at the top" (unethical behavior, lack of compliance with policies and procedures, incompetence or irresponsibility, etc.) can overcome comprehensive systems of internal control (Kizirian et al., 2005; Skaife et al., 2013). Firms with ineffective ICFR may allow managers excessive discretion over accounting choices and estimates due to lack of formal policies and procedures to limit these options (Hogan \& Wilkins, 2008). Hoitash et al. (2009) find that board and audit committee characteristics are associated with internal control quality, however, only under SOX 404 not 302.

More recently, Roychowdhury et al. (2019) review existing literature investigating the influence of financial reporting and disclosure on corporate investment decisions. They highlight how disclosure requirements and financial reporting regulation (for example, testing and reporting on ICFR) can induce managers to collect and process additional information that impacts managers' information sets and may alter their investment choices. The assertion underlying this research is that ICFR includes all the processes and procedures necessary to record the firm's transactions accurately. Ineffective internal controls can change the quality of managers' information, leading to lower quality information used in investment and management decisions.

Cheng et al. (2013) examine capital expenditures in firms with material weaknesses in ICFR and find these firms have lower investment efficiency in the predisclosure period. After the ICFR weaknesses are disclosed, the investment efficiency is improved. Harp and Barnes (2018) study firms with material weaknesses in ICFR in the context of mergers and acquisitions and find that ineffective ICFR at the acquiring firm has a significantly negative impact on post-acquisition operating performance and abnormal returns. Feng et al. (2015) investigate firms with ICFR material weaknesses relating to inventory and find these firms have lower inventory turnover ratios and more inventory impairments compared to firms with no inventory-related material weaknesses. These effects are mitigated for firms that remediate the inventory-related material weaknesses. Compared to firms that did not remediate, these firms also experienced improvements in sales, gross profit and operating cash flows. These studies support the presumption that ineffective ICFR may lead to negative operational outcomes for firms.

Gong et al. (2013) examine the effects of home country investor protection and ownership structure of cross-listed firms and find evidence that firms domiciled in weak investor protection countries are less likely to disclose deficiencies in internal control, suggesting the reluctance to disclose material weaknesses is motivated by management protecting its private benefits. Extending the research on country institutions, shareholder protections and corporate governance, Zhang (2018) examines the effect of enhanced governance on corporate reporting for Chinese firms after China's recent anti-corruption campaign initiative. Firms were found to be less likely to commit fraud in the post-campaign period due to the enhanced public governance 
which provided an additional source of external corporate monitoring. This effect was stronger for privately held firms, for firms in weak legal environments and for firms based in areas with poor local economy.

Garg et al. (2017) examine management certification of ICFR in Australia and find voluntary certification by $\mathrm{CEO}$ and $\mathrm{CFOs}$ to be negatively associated with discretionary accruals. Firms with voluntary ICFR certification are more likely to have solid corporate governance. Additionally, turnover of board of directors, audit committee members, and top management (i.e. CEO and/or CFO) are more likely when firms have ineffective ICFR (Johnstone et al., 2010; Li et al., 2010).

\subsection{Research Questions}

Our study considers a sample of foreign cross-listed firms and U.S. firms reporting internal control deficiencies in the audit report under SOX section 404 . We analyze the aftereffects of these disclosures for each type of firm from three perspectives: investors, auditors, and the companies themselves.

A limitation of this study is the small sample size, given that our population of interest is restricted to international firms trading in the U.S and reporting material weaknesses in ICFR. Additionally, much of the prior literature on the consequences of MWICFR cited above analyzes U.S. firms only. However, we note that prior literature documents differences in the disclosure quality of U.S. versus cross-listed firms due to various elements, including home country investor protections, auditors, corporate governance factors, culture and other institutional considerations. Because of this, we expect to observe not only differences in the consequences faced by cross-listed firms versus U.S. firms following audit reports disclosing material weaknesses in internal controls, but also differences among foreign firms. Our interests are concentrated in exploring the following research questions:

RQ1: are the aftereffects of reporting material weaknesses in ICFR similar for U.S. and foreign cross-listed firms?

RQ2: does the home market regulatory environment influence these potential aftereffects?

RQ3: does the use of a foreign auditor influence these potential aftereffects?

\section{RESEARCH SAMPLE AND METHODOLOGY}

\subsection{Data Analysis}

We utilize the Audit Analytics database to identify firms with material weaknesses in ICFR per the auditor's report from 2007 to 2016. We begin in 2007 given the effective date of SOX 404 for foreign private issuers and end in 2016 to allow collection of post-MWICFR data. Table 1 panel A details our sample selection procedures. As we are interested in examining only those firms with ineffective internal controls and a sample of U.S. versus foreign cross-listed firms, we eliminate those firms with effective or non-disclosed ICFR audit reports, those missing information on location of incorporation, and duplicate firm-year observations, leaving us with 1,984 firm-year observations. The sample is further restricted by data availability for the multivariate analysis and the removal of Canadian firms consistent with other crosslisting studies. ${ }^{4}$ We distinguish U.S. from foreign firms by country of incorporation,

\footnotetext{
${ }^{4}$ Leuz (2003) sets up a test for cross-listing effects on analyst coverage and analyst forecast accuracy using Canadian firms. He argues that since the multijurisdictional disclosure system exempts Canadian firms from U.S. reporting requirements this can be interpreted as disclosure requirements being comparable between the U.S. and Canada. Canadian firms can also directly
} 
consistent with Caban-Garcia et al. (2017). To ensure we are capturing foreign filers with the SEC, we examine firms' headquarters and SEC filings to further confirm their status. Thirty-two firm-year observations are removed from the sample due to being incorporated in a foreign jurisdiction despite having U.S. headquarters and filing 10-Ks as non-foreign filers with the SEC; thus, we deem them as having uncertain classification status for our study. ${ }^{5}$ The final sample consists of 1,155 firm-year observations, 141 foreign and 1,014 U.S.

Insert Table 1 here.

Table 1 panel B shows the breakdown of our sample by country. While we applied the filter discussed above to try to eliminate observations with foreign incorporation locations, but in essence operating as U.S. corporations, there exist observations in our sample incorporated in jurisdictions typically described as "tax havens". These firms are considered foreign-filers in their SEC form 20-F filings, however, we include an indicator variable, TaxHaven, in all multivariate analysis to identify and control for firm-year observations from those nations (Dyreng \& Lindsey, 2009).6,7

\subsection{Methodology}

Our study identifies the above sample of foreign and U.S. firms reporting deficiencies in internal controls over financial reporting under SOX section 404 and analyzes the aftereffects of these disclosures. More specifically, we examine: 1) how investors and creditors respond, as proxied by the equity and debt markets, 2) how the external auditors respond, as proxied by changes in audit fees, auditor resignations, and the likelihood of going concern opinions, and 3) how the company responds, as proxied by changes in the CFO and CEO positions.

As we are examining the consequences of reporting a MWICFR, we measure all variables in the year after the material weakness disclosure. To measure the equity market reaction, we utilized Eventus to conduct an event study around the filing of the auditor's report of a MWICFR. We utilized the equally weighted market index as the

list rather than "cross-list" on U.S. exchanges. Hail and Leuz (2009) employ a similar methodology.

5 The SEC has adopted a series of forms available to foreign private issuers, namely the Forms $20-\mathrm{F}$ and $6-\mathrm{K}$ disclosure forms for annual and current reports, respectively. The SEC allows foreign private issuers to voluntarily choose to register and report using domestic forms (e.g., "S" series registration statements and forms 10-K, 10-Q, and 8-K). However, these "firms would then lose some of the provisions available to foreign private issuers using the foreign filing regime (for example, foreign private issuers using the domestic forms must meet the earlier filing deadline of form 10-K, file form 10-Q quarterly reports, and file form 8-K current reports)" (SEC, 2013).

${ }^{6}$ Following the classification in Dyreng and Lindsey (2009), the jurisdictions in this paper classified as tax havens are: Antigua and Barbuda, Bermuda, Cayman Islands, Ireland, Luxembourg, Marshall Islands, Panama, Switzerland, and Virgin Islands (British \& U.S.).

7 As of May 2009, the committee on fiscal affairs for the organization for economic cooperation and development (OECD) has removed all remaining jurisdictions from its list of uncooperative tax havens due to commitments to implement the OECD standards of transparency and effective exchange of information: http://www.oecd.org/ countries/monaco/list-of-unco-operative-tax-havens.htm. However, we include this indicator variable for all years in our study to mitigate any potential issues. 
benchmark and produced the cumulative abnormal return (CAR) for each firm-year observation in the two-day window $(-1,0) .8$

Table 1

Sample Composition

\begin{tabular}{|c|c|c|c|c|}
\hline \multicolumn{5}{|c|}{ Panel A: Sample Selection } \\
\hline & & $\begin{array}{l}\text { Firm-Year } \\
\text { Observations }\end{array}$ & $\begin{array}{c}\text { Foreign } \\
\text { Firm-Year } \\
\text { Observations } \\
\end{array}$ & $\begin{array}{c}\text { U.S. Firm- } \\
\text { Year } \\
\text { Observations } \\
\end{array}$ \\
\hline \multicolumn{2}{|c|}{$\begin{array}{l}\text { Auditors' opinion from audit analytics } \\
\text { internal control database 2007-2017 }\end{array}$} & 40,47 & & \\
\hline \multicolumn{2}{|c|}{$\begin{array}{l}\text { Missing information on location of } \\
\text { incorporation }\end{array}$} & $(1,671)$ & & \\
\hline \multicolumn{2}{|c|}{$\begin{array}{l}\text { Internal control over financial reporting } \\
\text { (ICFR) is effective or not disclosed }\end{array}$} & $(36,705)$ & & \\
\hline \multicolumn{2}{|c|}{ Duplicate observations } & $(47)$ & & \\
\hline \multicolumn{2}{|c|}{ Number of ineffective ICFR } & 1,984 & 378 & 1,606 \\
\hline \multicolumn{2}{|c|}{$\begin{array}{l}\text { Compustat for variables of interest and } \\
\text { controls }\end{array}$} & (716) & (124) & (592) \\
\hline \multicolumn{2}{|c|}{$\begin{array}{l}\text { Removed Canadian firm-year } \\
\text { observations }\end{array}$} & (81) & (81) & - \\
\hline \multicolumn{2}{|c|}{$\begin{array}{l}\text { Remove firms headquartered in US \& } \\
\text { filling } 10-\mathrm{Ks}\end{array}$} & (32) & (32) & - \\
\hline \multicolumn{2}{|c|}{ Sample for analysis } & 1,155 & 141 & 1,014 \\
\hline \multicolumn{5}{|c|}{ Panel B: Sample by Country } \\
\hline Country & $\begin{array}{c}\text { Firm-Year } \\
\text { Observations }\end{array}$ & \multicolumn{2}{|c|}{ Country } & $\begin{array}{l}\text { Firm-Year } \\
\text { Observations }\end{array}$ \\
\hline Antigua and Barbuda & 2 & \multicolumn{2}{|c|}{ Korea (South) } & 2 \\
\hline Argentina & 5 & \multicolumn{2}{|c|}{ Luxembourg } & 2 \\
\hline Australia & 2 & \multicolumn{2}{|c|}{ Marshall Islands } & 7 \\
\hline Bermuda & 11 & \multicolumn{2}{|c|}{ Mexico } & 12 \\
\hline Brazil & 15 & \multicolumn{2}{|c|}{ Netherlands } & 2 \\
\hline Cayman Islands & 33 & \multicolumn{2}{|c|}{ Norway } & 1 \\
\hline Chile & 1 & \multicolumn{2}{|l|}{ Panama } & 1 \\
\hline China & 3 & \multicolumn{2}{|c|}{ Russia } & 9 \\
\hline Colombia & 1 & \multicolumn{2}{|c|}{ South Africa } & 1 \\
\hline France & 2 & \multicolumn{2}{|c|}{ Switzerland } & 2 \\
\hline Hungary & 1 & \multicolumn{2}{|c|}{ Turkey } & 1 \\
\hline India & 9 & \multicolumn{2}{|c|}{ United Kingdom } & 9 \\
\hline Indonesia & 1 & \multicolumn{2}{|c|}{ United States } & 1,014 \\
\hline Israel & 5 & & & 1,155 \\
\hline Italy & 1 & & & \\
\hline
\end{tabular}

Notes: this table details the sample composition; panel A shows the breakdown by firm-year from the audit analytics database; and panel B shows the sample distribution of MWICFR by country of incorporation.

\footnotetext{
${ }^{8}$ As discussed in Berkman and Truong (2006) and Hammersley et al. (2008), almost all of the price reaction to earnings news occurs by the end of a correctly specified day 0 . Reported conclusions are robust to examining the three-day window $(-1,+1)$ and are discussed in the next section.
} 
To capture the debt market reaction, we follow Hammersley et al. (2012) and calculate two measures. The first measure is the change in the Standard \& Poor's (S\&P) long-term domestic issuer senior credit rating from Compustat from the year of the reported MWICFR to the year after, where we convert the letter credit rating to a numeric range from 1 denoting the highest AAA and 17 denoting a rating of CCC + or lower. Thus, a positive change in credit rating ( $\Delta$ Rating) indicates a decreased rating and therefore, a higher cost of debt capital. The second measure is the change in interest rate, calculated as the change in interest expense divided by the average of short- and long-term debt from the year of the reported MWICFR to the year after. A positive change ( $\Delta$ InterestRate) indicates higher interest rates and therefore, a higher cost of debt capital.

There are three measures used to capture auditors' reactions to MWICFR, following Hammersley et al. (2012). The first is an indicator variable coded as one for auditor resignations per the audit analytics auditor change database, and 0 otherwise (resigned). The second measure captures the extent to which MWICFR increases auditor's concern about going concern risks and is coded as one for firm-year observations after a reported MWICFR that received a going concern audit opinion, and zero otherwise (GoingConcern). The last element of the auditors' reaction that is examined is the change in the natural log of audit fees after the MWICFR relative to the year of the MWICFR ( $\triangle \mathrm{LnAuditFees).}$

To measure firm response to reporting material weaknesses in ICFR we track changes in key management positions, specifically the $\mathrm{CFO}$ and $\mathrm{CEO}$, following the methodology in Johnstone et al. (2010) and Li et al. (2010). As the principal officers, the $\mathrm{CFO}$ and $\mathrm{CEO}$ are responsible for reviewing and certifying every annual report, as well as all the quarterly financial reports. CFO_change (CEO_change) is coded one when the chief financial officer (chief executive officer) changes in the year after the reported MWICFR and zero otherwise.

Utilizing the dependent variables described above, we conduct multivariate analyses to determine whether foreign cross-listed firms face different consequences following a MWICFR than U.S. firms. As such, in each regression we include an indicator variable, Foreign, coded one for firm-year observations for foreign cross-listed firms and zero for U.S. firms. In each consequence area, we run a regression with just this indicator plus control variables to first capture the main effect of whether foreign firms have different equity market, debt market, auditor, or firm reactions to MWICFR than U.S. firms. Specifically, we run the following (1) ordinary least squares (OLS) regressions and (2) logit regressions:

Consequence $_{\mathrm{i}, \mathrm{t}}=\alpha_{\mathrm{i}, \mathrm{t}}+\beta_{1}$ Foreign $_{\mathrm{i}, \mathrm{t}}+\beta_{2}$ Controls $_{\mathrm{i}, \mathrm{t}}+\beta_{3}$ Industry Fixed Effects $_{\mathrm{i}, \mathrm{t}}+\beta_{4}$ Year Fixed Effects $\mathrm{i}_{\mathrm{i}, \mathrm{t}}+\varepsilon_{\mathrm{i}, \mathrm{t}}$

Where: consequence is measured as CAR, $\Delta$ Rating, $\Delta$ InterestRate, and $\Delta$ LnAuditFees.

Logit $\left(\right.$ Consequence $\left.{ }_{i, t}\right)=\alpha_{i, t}+\beta_{1}$ Foreign $_{i, t}+\beta_{2}$ Controls $_{i, t}+\varepsilon_{i, t}$

Where: consequence is measured as resigned, going concern, $\mathrm{CFO}$ change, and CEO change.

However, as discussed in the previous sections, given the home markets and operating environments of foreign firms can differ from not only U.S. firms but also other foreign firms, we include two additional variables of interest in subsequent multivariate analysis. As the foreign regulatory market has been found to be an important factor in the cross-listing effect for foreign firms (e.g. Lang et al., 2006; Gong et al., 2013; and Wilford, 2016), we include the Rule of Law from the World Bank's Worldwide Governance Indicators (Kaufmann \& Kray, 2016). We utilize the percentile ranking of the measure divided by 100 , so that the variable RuleLaw ranges from zero 
to one, with higher numbers indicating more stringent regulatory environments. We interact this variable with Foreign to capture the extent the home regulatory environment influences the impact of internal control consequences relative to U.S. firms. Specifically, we run the following (3) OLS regressions and (4) logit regressions:

Consequence $_{i, t}=\alpha_{i, t}+\beta_{1}$ Foreign $_{i, t}+\beta_{2}$ RuleLaw $_{i, t}+\beta_{3}$ Foreign $^{*}$ RuleLaw $_{i, t}$ $+\beta_{4}$ Controls $_{i, t}+\beta_{5}$ Industry Fixed Effects $i_{i, t}$

$+\beta_{6}$ Year Fixed Effects $i_{i, t}+\varepsilon_{i, t}$

Where: consequence is measured as CAR, $\Delta$ Rating, $\Delta$ InterestRate, and $\Delta \mathrm{LnAuditFees}$.

$\left.\operatorname{Logit}_{(\text {Consequence }}, \mathrm{i}, \mathrm{t}\right)=\alpha_{\mathrm{i}, \mathrm{t}}+\beta_{1}$ Foreign $_{\mathrm{i}, \mathrm{t}}+\beta_{2}$ RuleLaw $_{\mathrm{i}, \mathrm{t}}+$ $\beta_{3}$ Foreign RuleLaw $w_{i, t}+\beta_{4}$ Controls $_{\mathrm{i}, \mathrm{t}}+\varepsilon_{\mathrm{i}, \mathrm{t}}$

Where: consequence is measured as resigned, GoingConcern, CFO_Change, and CEO_Change.

The second factor we examine is whether the firm's auditor is U.S. or foreign (ForeignAuditor). The impact that foreign auditors have in the aftermath of a material weakness in internal controls is a largely unexplored area of research, however, given research that supports that U.S.-based and foreign auditors provide varying levels of audit quality (e.g. Asthana et al., 2015; Ferguson, 2015), we believe this is an interesting additional factor to examine. Specifically, we run the following (5) OLS regressions and (6) logit regressions:

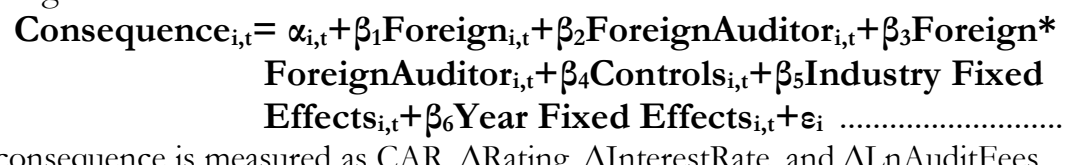

Where: consequence is measured as CAR, $\Delta$ Rating, $\Delta$ InterestRate, and $\Delta \mathrm{LnAuditFees}$

Logit $\left(\right.$ Consequence $\left.\mathrm{e}_{\mathrm{i}, \mathrm{t}}\right)=\alpha_{\mathrm{i}, \mathrm{t}}+\beta_{1}$ Foreign $_{\mathrm{i}, \mathrm{t}}+\beta_{2}$ ForeignAuditor $_{i, \mathrm{t}}+$ $\beta_{3}$ Foreign$*$ ForeignAuditor $_{\mathrm{i}, \mathrm{t}}+\beta_{4}$ Controls $_{\mathrm{i}, \mathrm{t}}+\varepsilon_{\mathrm{i}, \mathrm{t}} \ldots \ldots$....

Where: consequence is measured as resigned, GoingConcern, CFO_change, and CEO_change.

Caban-Garcia et al. (2017) suggest that the effectiveness of cross-listed firms' ICFR is influenced by the home market regulation and oversight. We extend this research by examining whether the home country regulation (RuleLaw) or type of oversight (ForeignAuditor) influences the consequences faced as a result of MWICFR. Equity market reactions, debt market reactions, audit environment changes, or management changes for foreign firms relative to U.S. firms may be offset by strong regulatory institutions in the home market and/or quality of the audit firm.

Throughout the multivariate analyses, we also control for other variables that may impact the results and are consistent with prior MWICFR consequence studies (e.g. Ashbaugh-Skaife et al., 2009; Johnstone et al., 2011; and Hammersley at al., 2012). We control for firm size (LnAssets), performance (ROA, loss, OperatingCF, and leverage), and complexity (LnBusSeg, LnGeoSeg, and RecInv). In regressions in which the dependent variable is a change variable, we correspondingly include the change of all control variables. We also include characteristics of the MWICFR, including the number of material weaknesses reported (CountMW) and whether the firm has reported multiple years of MWICFR during the sample period (RepeatMW) consistent with Hammersley et al. (2012). Lastly, we control for the size of the audit firm (Big 4), tax havens (TaxHaven), and include year and industry fixed effects in all OLS regressions.

\section{EMPIRICAL RESULTS}

Table 2 presents the univariate results, comparing the means of the variables for the two subsets of firms with MWICFR issues: foreign and U.S. Foreign firms have a significantly lower change in audit fees than U.S. firms with internal control issues. 
Foreign firms are also significantly less likely to have changes in key management positions after reporting internal control weaknesses. Foreign firms with MWICFR have a more negative CAR and a greater decrease in credit rating (as discussed above, positive values indicate a lowering of the letter credit rating) than U.S. MWICFR firms, though not at a statistically significant level in univariate analysis. However, foreign firms are significantly more likely to have a greater number of material weaknesses reported in the internal control report. Additionally, given that foreign and U.S. firms in the sample differ significantly on other firm characteristics as exhibited in Table 2 (ROA, OperatingCF, leverage, LnAssets, LnGeoSeg, RecInv, and book-to-market), it is important to conduct multivariate analyses, controlling for these factors, to determine if the consequences of MWICFR vary across the two groups.

Table 2

Descriptive Statistics

\begin{tabular}{ccc}
$\begin{array}{c}\text { Foreign } \\
\text { Firms }\end{array}$ & Firms & Diff. \\
$\mathbf{N}=141$ & $\mathbf{N}=1,014$ & \\
\hline
\end{tabular}

\begin{tabular}{|c|c|c|c|c|c|c|c|}
\hline & $\begin{array}{c}\text { Foreign } \\
\text { Firms } \\
\mathrm{N}=141\end{array}$ & $\begin{array}{c}\text { US } \\
\text { Firms } \\
\mathbf{N}=1,014\end{array}$ & Diff. & & $\begin{array}{c}\text { Foreign } \\
\text { Firms } \\
\mathrm{N}=141\end{array}$ & $\begin{array}{c}\text { US } \\
\text { Firms } \\
N=1,014\end{array}$ & Diff. \\
\hline$\overline{\text { CAR }}$ & -.006 & .003 & -.010 & LnAuditFees & 14.194 & 14.059 & .135 \\
\hline$\Delta$ Rating $^{\mathrm{a}}$ & .442 & .219 & .223 & Leverage & .156 & .218 & $-.062^{* * *}$ \\
\hline$\Delta$ InterestRate $^{\mathrm{a}}$ & .225 & .228 & -.003 & LnAssets & 7.737 & 6.510 & $1.227^{* * *}$ \\
\hline$\Delta$ LnAuditFees & -.068 & .025 & $-.093^{* *}$ & LnBusSeg & .810 & .735 & .075 \\
\hline Resigned & .021 & .031 & -.009 & LnGeoSeg & .974 & .772 & $.202^{* * *}$ \\
\hline GoingConcern & .057 & .046 & .010 & RecInv & .218 & .261 & $-.043^{* *}$ \\
\hline CFO_Change & .021 & .266 & $-.245^{* * *}$ & Book-to-Market & 1.113 & .687 & $.426^{* * *}$ \\
\hline CEO_Change & .014 & .172 & $-.157^{* * *}$ & $\Delta$ LnAssets & .037 & .005 & .032 \\
\hline RuleL̃aw & .644 & .914 & $-.270^{* * *}$ & $\Delta$ LnBusSeg & .099 & .026 & $.073^{* *}$ \\
\hline ForeignAuditor & .936 & .036 & $.900^{* * * *}$ & $\Delta$ LnGeoSeg & .148 & .045 & $.103^{* * *}$ \\
\hline RepeatMW & .518 & .566 & -.048 & $\Delta \operatorname{RecInv}$ & -.010 & .000 & $-.010^{* *}$ \\
\hline CountMW & 2.518 & 1.829 & $.688^{* * *}$ & $\triangle \mathrm{ROA}$ & .010 & -.008 & .018 \\
\hline TaxHaven & .461 & .000 & $.461^{* * *}$ & $\Delta$ Loss & .021 & .013 & .008 \\
\hline Big 4 & .766 & .687 & $.078^{*}$ & $\Delta$ GoingConcern & .000 & .011 & -.011 \\
\hline ROA & .014 & -.073 & $.088^{* *}$ & $\Delta$ Big 4 & -.043 & -.008 & -.035 \\
\hline Loss & .433 & .453 & -.020 & $\Delta$ OperatingCF & .025 & -.002 & $.027^{* *}$ \\
\hline OperatingCF & .055 & .020 & $.035^{* *}$ & $\Delta$ Leverage & .011 & .012 & -.001 \\
\hline
\end{tabular}

Notes: Table 2 shows the means of the variables of interest and control variables used in the multivariate analysis in the tables that follow. All variables are defined in Appendix A. Ttests were conducted on the difference in means between the two groups. ${ }^{* * *}$, ${ }^{* *}$, and ${ }^{*}$ denote statistical significance at the $1 \%, 5 \%$, and $10 \%$ levels, respectively. ${ }^{a}$ Indicates the sample size for $\Delta$ Ratings and $\Delta$ InterestRate is reduced for these variables as reported in the regressions in Table 4.

The first analysis examines the equity market's reaction to the published MWICFR opinion. The first column in Table 3 shows that foreign firms MWICFR is met with a negative and significant stock market reaction compared to their U.S. counterparts, providing evidence that foreign firms suffer marginally greater equity market consequences than U.S. firms after internal control issues. This confirms findings from prior literature that there are significant differences in financial reporting between cross-listed and U.S. firms (Lang et al., 2006). The next two columns further condition the sample on properties of the foreign firm's home market and auditor. Table 3, column 2, shows that this negative market reaction for foreign firms is significantly mitigated as the rule of law strengthens. The last column of Table 3 shows that whether a firm is audited by a U.S. or foreign auditor does not impact the equity market's significant and negative reaction to foreign firm material weakness issues 
compared to U.S. firms. Thus, foreign firms suffer a more negative consequence in the equity market after issuing a MWICFR than U.S. firms, but this impact is lessened for those firms from stronger regulatory environments, in line with findings from Doidge et al. (2004), Lang et al. (2006), and Hail and Leuz (2009) and others on the importance of cross-listed firms' home markets. ${ }^{9}, 10$

Table 3

Stock Market Reaction

\begin{tabular}{|c|c|c|c|c|c|c|c|}
\hline & \multicolumn{3}{|c|}{$\operatorname{CAR}(-1,0)$} & & \multicolumn{3}{|c|}{ CAR $(-1,0)$} \\
\hline & (1) & (2) & (3) & & (1) & $(2)$ & (3) \\
\hline Foreign & $\begin{array}{l}-.012^{*} \\
(1.72)\end{array}$ & $\begin{array}{l}-.739^{* * *} \\
(7.00)\end{array}$ & $\begin{array}{l}-.058^{* *} \\
(2.18)\end{array}$ & RepeatMW & $\begin{array}{l}-.009 \\
(1.56)\end{array}$ & $\begin{array}{l}-.008 \\
(1.40)\end{array}$ & $\begin{array}{l}-.009 \\
(1.57)\end{array}$ \\
\hline RuleLaw & & $\begin{array}{l}-.748^{* * *} \\
(6.72)\end{array}$ & $\begin{array}{l}.001 \\
(.02)\end{array}$ & CountMW & $\begin{array}{l}.001 \\
(.64)\end{array}$ & $\begin{array}{l}.001 \\
(.83)\end{array}$ & $\begin{array}{l}.001 \\
(.67)\end{array}$ \\
\hline ForeignAuditor & & $\begin{array}{l}.021 \\
(.96)\end{array}$ & $\begin{array}{l}.123 \\
.36\end{array}$ & Leverage & $\begin{array}{l}.022^{*} \\
(1.93)\end{array}$ & $\begin{array}{l}.024^{* *} \\
(2.11)\end{array}$ & $\begin{array}{l}.023^{* *} \\
(1.97)\end{array}$ \\
\hline $\begin{array}{l}\text { Foreign*Rule- } \\
\text { Law }\end{array}$ & & $\begin{array}{l}.784^{* * *} \\
(6.89)\end{array}$ & & Book-to-Market & $\begin{array}{l}.004^{*} \\
(1.66)\end{array}$ & $\begin{array}{l}.004^{*} \\
(1.76)\end{array}$ & $\begin{array}{l}.004^{*} \\
(1.72)\end{array}$ \\
\hline $\begin{array}{l}\text { Foreign* } \\
\text { ForeignAuditor }\end{array}$ & & & $(1.03)$ & OperatingCF & $\begin{array}{l}-.003 \\
(.16)\end{array}$ & $\begin{array}{l}.000 \\
(.02)\end{array}$ & $\begin{array}{l}-.003 \\
(.14)\end{array}$ \\
\hline ROA & $\begin{array}{l}.015 \\
(.97)\end{array}$ & $\begin{array}{l}.013 \\
(.82)\end{array}$ & $\begin{array}{l}.015 \\
(.97)\end{array}$ & TaxHaven & $\begin{array}{l}-.006 \\
(.57)\end{array}$ & $\begin{array}{r}-.007 \\
(.65)\end{array}$ & $\begin{array}{l}-.001 \\
(-.06)\end{array}$ \\
\hline Loss & $\begin{array}{l}-.003 \\
(.46)\end{array}$ & $\begin{aligned}-.002 \\
(.46)\end{aligned}$ & $\begin{array}{c}-.002 \\
(.36)\end{array}$ & Constant & $\begin{array}{l}.022 \\
(1.02)\end{array}$ & $\begin{array}{l}.709^{* * *} \\
(6.86)\end{array}$ & $\begin{array}{l}.023 \\
(.96)\end{array}$ \\
\hline GoingConcern & $\begin{array}{l}.003 \\
(.26)\end{array}$ & $\begin{array}{l}.001 \\
(.04)\end{array}$ & $\begin{array}{l}.002 \\
(.16)\end{array}$ & $\begin{array}{l}\text { Industry Fixed Effects } \\
\text { Year Fixed Effects }\end{array}$ & $\begin{array}{l}\text { Yes } \\
\text { Yes }\end{array}$ & $\begin{array}{l}\text { Yes } \\
\text { Yes }\end{array}$ & $\begin{array}{l}\text { Yes } \\
\text { Yes }\end{array}$ \\
\hline Big 4 & $\begin{array}{r}.006 \\
(1.03) \\
\end{array}$ & $\begin{array}{l}.007 \\
(1.20) \\
\end{array}$ & $\begin{array}{l}.005 \\
(.90) \\
\end{array}$ & $\begin{array}{l}\text { Observations } \\
\text { R-squared }\end{array}$ & $\begin{array}{c}1,121 \\
.10 \\
\end{array}$ & $\begin{array}{c}1,121 \\
.12 \\
\end{array}$ & $\begin{array}{c}1,121 \\
.10\end{array}$ \\
\hline
\end{tabular}

Notes: this table presents the results of OLS regressions, where the dependent variable is the cumulative abnormal return (CAR) around the issuance of the audit report containing the material weakness. All variables are defined in Appendix A. T-statistics are reported below the coefficients. ${ }^{* * *},{ }^{* *}$, and ${ }^{*}$ denote statistical significance at the $1 \%, 5 \%$, and $10 \%$ levels, respectively.

Table 4 presents the results analyzing the cost of debt for material weakness firms. The first (last) three columns utilize the change in S\&P credit rating (change in interest rate) from the year after compared to the year before a MWCIFR. While the sample size is significantly reduced due to data availability for credit ratings, the results in column 1 show that foreign firms experience a significant change in credit ratings, with the significant positive coefficient implying a greater risk of default for foreign as opposed to U.S. firms. Thus, the debt market enacts a harsher consequence on foreign cross-listed firms than U.S. firms with internal control issues, consistent with the results reported above for equity markets. The results are in line with findings from prior literature that cross-listed bonds are more likely than U.S. bonds to be rated conservatively and less likely to receive upgrades (Atilgan et al., 2015).

\footnotetext{
${ }^{9}$ We lose 34 firm-year observations due to availability for calculating book-to-market. Thirtythree of these observations come from US firm-year observations, thus this sample attrition does not appear to bias or results. We perform the same tests without book-to-market and find quantitatively and qualitatively similar results.

${ }^{10}$ Using the CAR $(-1,1)$ window, we reach similar conclusions regarding equity market consequences for foreign firms based on regulatory environments. The coefficient on foreign (Foreign*RuleLaw) is significantly negative (positive) at the $1 \%$ level.
} 
This debt market punishment is not, however, impacted by RuleLaw or ForeignAuditor as shown in columns 2 and 3. However, when examining another aspect of the cost of debt, $\Delta$ InterestRate, we find significant results only when conditioning on the home market regulatory environment. The results in column 4 show that while foreign firms experience a significant increase in interest rates (i.e. higher cost of debt) than U.S. firms, this increase is mitigated as the strength of the regulatory environment increases, consistent with prior literature highlighting the importance of the home market environments for cross-listed firms (Gong et al., 2013; Hope et al., 2013; and Srinivasan et al., 2015). Once again, we find that the location of the audit firm has no impact on creditors' view of MWICFR firms. Overall, the results in Tables 3 and 4 provide evidence that both the equity and debt markets enact harsher punishments on foreign cross-listed firms compared to U.S. firms for reporting material weaknesses. Additionally, this negative equity market reaction and higher interest rates in the debt market are mitigated as the home regulatory environment becomes stronger.

Table 4

Debt Market Reaction

\begin{tabular}{|c|c|c|c|c|c|c|}
\hline & \multicolumn{3}{|c|}{$\Delta$ Rating } & \multicolumn{3}{|c|}{$\Delta$ InterestRate } \\
\hline & (1) & (2) & (3) & (4) & (5) & (6) \\
\hline Foreign & $\begin{array}{l}.491^{* *} \\
(2.34)\end{array}$ & $\begin{array}{c}-23.940 \\
(1.57)\end{array}$ & $\begin{array}{c}1.347^{* *} \\
(2.31)\end{array}$ & $\begin{array}{c}-.086 \\
(.20)\end{array}$ & $\begin{array}{c}2.416^{* *} \\
(2.10)\end{array}$ & $\begin{array}{c}-.099 \\
(.30)\end{array}$ \\
\hline RuleLaw & & $\begin{array}{c}-26.640 \\
(1.58)\end{array}$ & $\begin{array}{l}.018 \\
(.02)\end{array}$ & & $\begin{array}{l}2.101^{*} \\
(1.83)\end{array}$ & $\begin{array}{r}-.065 \\
(.08)\end{array}$ \\
\hline ForeignAuditor & & $\begin{array}{l}.027 \\
(.07)\end{array}$ & $\begin{array}{l}.147 \\
(.31)\end{array}$ & & $\begin{array}{c}-.416 \\
(.88)\end{array}$ & $\begin{array}{c}-.525 \\
(.89)\end{array}$ \\
\hline Foreign*RuleLaw & & $\begin{array}{c}26.620 \\
(1.60)\end{array}$ & & & $\begin{array}{c}-2.463^{* *} \\
(1.99)\end{array}$ & \\
\hline Foreign*Foreign-Auditor & & & $\begin{array}{c}-1.014 \\
(1.29)\end{array}$ & & & $\begin{array}{l}.504 \\
(.90)\end{array}$ \\
\hline$\triangle \mathrm{ROA}$ & $\begin{array}{l}.817^{*} \\
(1.86)\end{array}$ & $\begin{array}{l}.782^{*} \\
(1.80)\end{array}$ & $\begin{array}{l}.809^{*} \\
(1.88)\end{array}$ & $\begin{array}{l}.047 \\
(.16)\end{array}$ & $\begin{array}{l}.057 \\
.20)\end{array}$ & $\begin{array}{l}.066 \\
(.22)\end{array}$ \\
\hline$\Delta$ Loss & $\begin{array}{l}-.306^{*} \\
(1.83)\end{array}$ & $\begin{array}{c}-.332^{* *} \\
(1.99)\end{array}$ & $\begin{array}{l}-.308^{*} \\
(1.84)\end{array}$ & $\begin{array}{c}.359^{*} \\
(1.68)\end{array}$ & $\begin{array}{l}.363^{*} \\
(1.65)\end{array}$ & $\begin{array}{c}.363 \\
(1.64)\end{array}$ \\
\hline$\Delta$ LnAssets & $\begin{array}{l}-.117 \\
(.47)\end{array}$ & $\begin{array}{c}-.168 \\
(.69)\end{array}$ & $\begin{array}{l}-.129 \\
. .51)\end{array}$ & $\begin{array}{l}-.385 \\
(1.25)\end{array}$ & $\begin{array}{l}-.377 \\
(1.26)\end{array}$ & $\begin{array}{l}-.366 \\
(1.25)\end{array}$ \\
\hline$\Delta$ Leverage & $\begin{array}{c}.730 \\
(1.23)\end{array}$ & $\begin{array}{c}.715 \\
(1.20)\end{array}$ & $\begin{array}{c}.706 \\
(1.17)\end{array}$ & $\begin{array}{c}-.138 \\
(.22)\end{array}$ & $\begin{array}{c}-.119 \\
(.18)\end{array}$ & $\begin{array}{r}-.127 \\
(.20)\end{array}$ \\
\hline$\Delta$ GoingConcern & $\begin{array}{l}.941^{* * *} \\
(2.63)\end{array}$ & $\begin{array}{l}.939^{* *} \\
(2.35)\end{array}$ & $\begin{array}{l}.977^{* *} \\
(2.34)\end{array}$ & $\begin{array}{r}-.063 \\
(.43)\end{array}$ & $\begin{array}{c}-.062 \\
(.43)\end{array}$ & $\begin{array}{c}-.073 \\
(.51)\end{array}$ \\
\hline$\Delta \mathrm{Big} 4$ & $\begin{array}{l}-.722^{*} \\
(1.84)\end{array}$ & $\begin{array}{l}-.802^{* *} \\
(2.18)\end{array}$ & $\begin{array}{l}-.731^{*} \\
(1.91)\end{array}$ & $\begin{array}{l}.017 \\
.09)\end{array}$ & $\begin{array}{l}.036 \\
(.19)\end{array}$ & $\begin{array}{l}.033 \\
(.18)\end{array}$ \\
\hline$\triangle$ OperatingCF & $\begin{array}{c}-.599 \\
(.44)\end{array}$ & $\begin{array}{r}-.865 \\
(.63)\end{array}$ & $\begin{array}{l}-.496 \\
(.35)\end{array}$ & $\begin{array}{r}-.510 \\
(1.14)\end{array}$ & $\begin{array}{l}-.530 \\
(1.17)\end{array}$ & $\begin{array}{r}-.529 \\
(1.16)\end{array}$ \\
\hline ROA & $\begin{array}{c}-1.704^{* * *} \\
(2.72)\end{array}$ & $\begin{array}{c}-1.645^{* *} \\
(2.59)\end{array}$ & $\begin{array}{c}-1.689^{* * *} \\
(2.67)\end{array}$ & $\begin{array}{c}-.090 \\
. .29)\end{array}$ & $\begin{array}{l}-.107 \\
(.33)\end{array}$ & $\begin{array}{r}-.131 \\
(.38)\end{array}$ \\
\hline Leverage & $\begin{array}{r}-.089 \\
(.27)\end{array}$ & $\begin{array}{r}-.106 \\
(.32)\end{array}$ & $\begin{array}{l}-.07 \\
(.21)\end{array}$ & $\begin{array}{l}-.682 \\
(1.28)\end{array}$ & $\begin{array}{l}-.705 \\
(1.30)\end{array}$ & $\begin{array}{l}-.697 \\
(1.28)\end{array}$ \\
\hline Loss & $\begin{array}{l}.626^{* * *} \\
(3.27)\end{array}$ & $\begin{array}{l}.678^{* * *} \\
(3.47)\end{array}$ & $\begin{array}{l}.617^{* * *} \\
(3.22)\end{array}$ & $\begin{array}{r}-.472^{*} \\
(1.65)\end{array}$ & $\begin{array}{l}-.481 \\
(1.62)\end{array}$ & $\begin{array}{c}-.478 \\
(1.62)\end{array}$ \\
\hline LnAssets & $\begin{array}{c}.074 \\
(1.16)\end{array}$ & $\begin{array}{c}.077 \\
(1.15)\end{array}$ & $\begin{array}{c}.083 \\
(1.19)\end{array}$ & $\begin{array}{l}-.082^{* *} \\
(2.02)\end{array}$ & $\begin{array}{l}-.082^{* *} \\
(1.99)\end{array}$ & $\begin{array}{l}-.084^{4} \\
(2.02)\end{array}$ \\
\hline GoingConcern & $\begin{array}{c}-.122 \\
(.38)\end{array}$ & $\begin{array}{c}-.176 \\
(.52)\end{array}$ & $\begin{array}{c}-.159 \\
(.46)\end{array}$ & $\begin{array}{l}-.210 \\
(.54)\end{array}$ & $\begin{array}{r}-.177 \\
(.51)\end{array}$ & $\begin{array}{c}-.174 \\
(.50)\end{array}$ \\
\hline
\end{tabular}


To be continued from Table 4.

\begin{tabular}{lcccccc}
\hline & \multicolumn{3}{c}{$\Delta$ Rating } & \multicolumn{3}{c}{$\Delta$ InterestRate } \\
\cline { 2 - 7 } Big4 & $\mathbf{( 1 )}$ & $\mathbf{( 2 )}$ & $\mathbf{( 3 )}$ & $\mathbf{( 4 )}$ & $\mathbf{( 5 )}$ & $\mathbf{( 6 )}$ \\
\hline RepeatMW & .209 & .180 & .188 & .092 & .092 & .100 \\
& $(.95)$ & $(.82)$ & $(.86)$ & $(.38)$ & $(.37)$ & $(.40)$ \\
CountMW & -.054 & -.046 & -.052 & -.336 & -.332 & -.327 \\
& $(.36)$ & $(.30)$ & $(.35)$ & $(.83)$ & $(.84)$ & $(.84)$ \\
OperatingCF & -.014 & -.014 & -.014 & $.077^{*}$ & $.076^{*}$ & $.076^{*}$ \\
& $(.43)$ & $(.41)$ & $(.43)$ & $(1.75)$ & $(1.72)$ & $(1.71)$ \\
TaxHaven & -1.676 & -1.422 & -1.677 & .194 & .215 & .237 \\
& $(1.29)$ & $(1.10)$ & $(1.28)$ & $. .61)$ & $(.68)$ & $(.74)$ \\
Constant & -.239 & -.257 & -.378 & -.085 & -.057 & -.079 \\
Industry Fixed Effects & $. .56)$ & $. .62)$ & $(.76)$ & $(.26)$ & $(.24)$ & $(.33)$ \\
Year Fixed Effects & -.545 & 23.990 & -.622 & $.641^{*}$ & -1.303 & .712 \\
Observations & $(.94)$ & $(1.55)$ & $(.82)$ & $(1.80)$ & $(1.32)$ & $(1.07)$ \\
R-squared & Yes & Yes & Yes & Yes & Yes & Yes \\
\hline Notes: This table preses & Yes & Yes & Yes & Yes & Yes & Yes \\
& 290 & 290 & 290 & 1,083 & 1,083 & 1,083 \\
& .39 & .40 & .39 & .06 & .06 & .06 \\
\hline
\end{tabular}

Notes: This table presents the results of OLS regressions, where the dependent variable is the change in S\&P credit rating (columns 1-3) or the change in interest rate (columns 4-6), following a MWICFR. All variables are defined in Appendix A. T-statistics are reported below the coefficients. ${ }^{* *}$, ${ }^{* *}$, and ${ }^{*}$ denote statistical significance at the $1 \%, 5 \%$, and $10 \%$ levels, respectively.

The next three tables move from the external market reaction to the auditor's reaction to MWICFR. Table 5 analyzes whether auditor's respond to a MWICFR by resigning from the engagement. Column 1's results show that overall foreign firms are less likely to have their auditors resign after reporting a material weakness, however, the coefficient is statistically insignificant. This lack of significance is consistent with the findings in Hammersley et al. (2012) that even non-remediating versus remediating MWICFR firms do not report significantly different auditor resignation rates, thus auditor resignation may not be an immediate consequence for MWICFR firms. However, once we condition on the home market environment, we find that foreign firms are significantly less likely to have their auditors resign than U.S. firms, but foreign firms from stronger regulatory environments are more likely to be faced with auditor resignations, reflecting evidence consistent with the importance of the home market in mitigating cross-listing effects (Wilford, 2016; Caban-Garcia et al., 2017). Turning to the last column of Table 5, foreign firms with foreign auditors are significantly less likely to suffer the consequences of having their auditor resign, which may reflect the lower litigation risk faced by auditors outside of the U.S. (Seetharaman et al., 2002). These results indicate that the strength of home market institutions may force more auditors to rid themselves of clients with internal control issues, whereas foreign firms with auditors from their home markets are less likely to face auditor resignations.

Insert Table 5 here.

Somewhat similar results are also reflected in Table 6. Foreign firms are marginally more likely to receive going concern reports in the year subsequent to disclosing a MWICFR. Turning to potential mitigating conditions that may impact this relationship, we find that while the home market regulatory environment has no impact on the audit opinion issuance (column 2), foreign firms with foreign auditors are significantly less likely to receive a going concern audit opinion (column 3). The final 
test of audit market consequences shown in Table 7, the change in audit fees, produces no significant results, for both the overall comparison of U.S. versus foreign firms and conditioning on RuleLaw or ForeignAuditor.

Table 5

Auditor Resignation

\begin{tabular}{|c|c|c|c|c|c|c|c|}
\hline & \multicolumn{3}{|c|}{ Logit(Resigned) } & & \multicolumn{3}{|c|}{ Logit(Resigned) } \\
\hline & (1) & (2) & (3) & & $(1)$ & (2) & (3) \\
\hline Foreign & $\begin{array}{l}-1.270 \\
(0.91)\end{array}$ & $\begin{array}{c}-6.356^{*} \\
(1.91)\end{array}$ & $\begin{array}{l}0.999 \\
(0.56)\end{array}$ & CountMW & $\begin{array}{l}0.149^{* *} \\
(2.55)\end{array}$ & $\begin{array}{l}0.162^{* * *} \\
(2.75)\end{array}$ & $\begin{array}{l}0.163^{* * *} \\
(2.72)\end{array}$ \\
\hline RuleLaw & & $\begin{array}{l}-2.186 \\
(0.83)\end{array}$ & $\begin{array}{l}1.095 \\
(0.73)\end{array}$ & TaxHaven & $\begin{array}{l}1.682 \\
(1.06)\end{array}$ & $\begin{array}{l}0.620 \\
(0.52)\end{array}$ & $\begin{array}{l}1.037 \\
(0.64)\end{array}$ \\
\hline ForeignAuditor & & $\begin{array}{l}0.947 \\
(1.03)\end{array}$ & $\begin{array}{l}1.354^{* *} \\
(1.99)\end{array}$ & LnAuditFees & $\begin{array}{l}-0.075 \\
(0.36)\end{array}$ & $\begin{array}{l}-0.052 \\
(0.24)\end{array}$ & $\begin{array}{l}-0.050 \\
(0.22)\end{array}$ \\
\hline $\begin{array}{l}\text { Foreign*Rule- } \\
\text { Law }\end{array}$ & & $\begin{array}{l}6.313^{*} \\
(1.83)\end{array}$ & & GoingConcern & $\begin{array}{l}-0.223 \\
(0.24)\end{array}$ & $\begin{array}{l}-0.310 \\
(0.33)\end{array}$ & $\begin{array}{l}-0.447 \\
(0.46)\end{array}$ \\
\hline $\begin{array}{l}\text { Foreign*Fore- } \\
\text { ignAuditor }\end{array}$ & & & $\begin{array}{c}-3.226^{* *} \\
(2.21)\end{array}$ & OperatingCF & $\begin{array}{l}0.714 \\
(0.84)\end{array}$ & $\begin{array}{l}0.723 \\
(0.84)\end{array}$ & $\begin{array}{l}0.719 \\
(0.84)\end{array}$ \\
\hline $\mathrm{ROA}$ & $\begin{array}{l}-1.007 \\
(1.53)\end{array}$ & $\begin{array}{l}-1.044 \\
(1.56)\end{array}$ & $\begin{array}{l}-1.104^{*} \\
(-1.65)\end{array}$ & CFO_Change & $\begin{array}{l}0.301 \\
(0.75)\end{array}$ & $\begin{array}{l}0.307 \\
(0.76)\end{array}$ & $\begin{array}{l}0.295 \\
(0.73)\end{array}$ \\
\hline Leverage & $\begin{array}{l}-0.473 \\
(0.56)\end{array}$ & $\begin{array}{l}-0.445 \\
(0.53)\end{array}$ & $\begin{array}{l}-0.439 \\
(0.53)\end{array}$ & CEO_Change & $\begin{array}{l}0.441 \\
(0.93)\end{array}$ & $\begin{array}{l}0.483 \\
(1.01)\end{array}$ & $\begin{array}{l}0.503 \\
(1.04)\end{array}$ \\
\hline Loss & $\begin{array}{l}-0.342 \\
(0.81)\end{array}$ & $\begin{array}{l}-0.356 \\
(0.82)\end{array}$ & $\begin{array}{l}-0.443 \\
(0.98)\end{array}$ & Constant & $\begin{array}{l}-2.590 \\
(0.93)\end{array}$ & $\begin{array}{l}-0.971 \\
(0.28)\end{array}$ & $\begin{array}{l}-3.990 \\
(1.36)\end{array}$ \\
\hline Big 4 & $\begin{array}{l}-0.771^{*} \\
(1.83)\end{array}$ & $\begin{array}{c}-0.831^{* *} \\
(2.05)\end{array}$ & $\begin{array}{c}-0.837^{* *} \\
(2.04)\end{array}$ & $\begin{array}{l}\text { Observations } \\
\text { Pseudo R- }\end{array}$ & $\begin{array}{l}1,155 \\
0.06\end{array}$ & $\begin{array}{l}1,155 \\
0.07\end{array}$ & $\begin{array}{c}1,155 \\
0.07\end{array}$ \\
\hline RepeatMW & $\begin{array}{l}0.461 \\
(1.17)\end{array}$ & $\begin{array}{l}0.466 \\
(1.16)\end{array}$ & $\begin{array}{l}0.454 \\
(1.15)\end{array}$ & squared & & & \\
\hline
\end{tabular}

Notes: this table presents the results of logit regressions, where the dependent variable captures if the auditor resigned following a MWICFR. All variables are defined in Appendix A. Zstatistics are reported below the coefficients. ${ }^{* *},{ }^{* *}$, and ${ }^{*}$ denote statistical significance at Table 6 the $1 \%, 5 \%$, and $10 \%$ levels, respectively.

Going Concern

\begin{tabular}{lccc}
\hline & \multicolumn{3}{c}{ Logit(GoingConcern) } \\
\cline { 2 - 4 } Foreign & $\mathbf{( 1 )}$ & $\mathbf{( 2 )}$ & $\mathbf{( 3 )}$ \\
\hline & $(-1.74)$ & $(-1.23)$ & $(-.81)$ \\
RuleLaw & & 20.680 & -3.294 \\
Foreign- & & $(-1.20)$ & $(-1.22)$ \\
Auditor & & $1.708^{* *}$ & $2.001^{* * *}$ \\
Foreign* & & $-2.24)$ & $(-2.81)$ \\
RuleLaw & & -23.150 & \\
Foreign* & & & $-3.235^{* *}$ \\
Foreign- & & & $(-2.42)$ \\
Auditor & & & \\
ROA & $-1.837^{* * *}$ & $-1.956^{* * *}$ & $-1.948^{* * *}$ \\
& $(-4.30)$ & $(-4.48)$ & $(-4.38)$ \\
Leverage & -.261 & -.363 & -.358 \\
& $(-.38)$ & $(-.50)$ & $(-.50)$ \\
Loss & $1.392^{* * *}$ & $1.540^{* * *}$ & $1.615^{* * *}$ \\
& $(-3.34)$ & $(-3.44)$ & $(-3.48)$ \\
\hline
\end{tabular}

\begin{tabular}{lccc}
\hline & \multicolumn{3}{c}{ Logit(GoingConcern) } \\
\cline { 2 - 4 } & $\mathbf{( 1 )}$ & $\mathbf{( 2 )}$ & $\mathbf{( 3 )}$ \\
\hline LnAssets & .083 & .109 & .122 \\
& $(-.67)$ & $(-.81)$ & $(-.91)$ \\
Big 4 & .310 & .215 & .176 \\
& $(-.63)$ & $(-.43)$ & $(-.36)$ \\
CountMW & .013 & .026 & .024 \\
& $(-.25)$ & $(-.53)$ & $(-.48)$ \\
RepeatMW & .590 & .500 & .414 \\
GoingCon- & $(-1.46)$ & $(-1.15)$ & $(-.98)$ \\
cern_Prior- & $4.116^{* * *}$ & $3.945^{* * *}$ & $3.971^{* * *}$ \\
Year & $(-8.41)$ & $(-7.67)$ & $(-7.93)$ \\
TaxHaven & $-1.844^{* *}$ & -.807 & -.983 \\
& $(-2.19)$ & $(-.73)$ & $(-.95)$ \\
Constant & $-6.100^{* * *}$ & -25.38 & -3.487 \\
& $(-6.68)$ & $(-1.60)$ & $(-1.29)$ \\
Observations & 1,155 & 1,155 & 1,155 \\
Pseudo R- & .41 & .43 & .44 \\
squared & & &
\end{tabular}


Notes: this table presents the results of logit regressions, where the dependent variable measures whether the auditor issued a going-concern audit opinion following a MWICFR. All variables are defined in Appendix A. Z-statistics are reported below the coefficients. ${ }^{* * *}$, **, and ${ }^{*}$ denote statistical significance at the $1 \%, 5 \%$, and $10 \%$ levels, respectively.

Table 7

Changes in Audit Fees

\begin{tabular}{|c|c|c|c|c|c|c|c|}
\hline & \multicolumn{3}{|c|}{$\Delta$ LnAuditFees } & & \multicolumn{3}{|c|}{$\Delta$ LnAuditFees } \\
\hline & (1) & (2) & (3) & & (1) & (2) & (3) \\
\hline Foreign & $\begin{array}{l}-.035 \\
(.54)\end{array}$ & $\begin{array}{l}.089 \\
(.16)\end{array}$ & $\begin{array}{l}.092 \\
(.76)\end{array}$ & LnBusSeg & $\begin{array}{c}.044 \\
(1.62)\end{array}$ & $\begin{array}{c}.045 \\
(1.64)\end{array}$ & $\begin{array}{c}.045 \\
(1.64)\end{array}$ \\
\hline RuleLaw & & $\begin{array}{l}.045 \\
(.07)\end{array}$ & $\begin{array}{l}-.069 \\
(.36)\end{array}$ & LnGeoSeg & $\begin{array}{l}-.003 \\
(.12)\end{array}$ & $\begin{array}{l}-.001 \\
(.02)\end{array}$ & $\begin{array}{l}.000 \\
(.02)\end{array}$ \\
\hline $\begin{array}{l}\text { ForeignAudi- } \\
\text { tor }\end{array}$ & & $\begin{array}{l}-.058 \\
(.90)\end{array}$ & $\begin{array}{l}-.034 \\
(.45)\end{array}$ & RecInv & $\begin{array}{l}.096 \\
(1.19)\end{array}$ & $\begin{array}{l}.094 \\
(1.16)\end{array}$ & $\begin{array}{l}.100 \\
(1.22)\end{array}$ \\
\hline $\begin{array}{l}\text { Foreign* } \\
\text { RuleLaw }\end{array}$ & & $\begin{array}{l}-.096 \\
(.15)\end{array}$ & & ROA & $\begin{array}{l}-.085 \\
(1.22)\end{array}$ & $\begin{array}{c}-.08 \\
(1.18)\end{array}$ & $\begin{array}{l}-.084 \\
(1.19)\end{array}$ \\
\hline $\begin{array}{l}\text { Foreign*Fo- } \\
\text { reignAuditor }\end{array}$ & & & $\begin{array}{l}-.124 \\
(.95)\end{array}$ & Loss & $\begin{array}{l}.013 \\
(.37)\end{array}$ & $\begin{array}{l}.013 \\
(.37)\end{array}$ & $\begin{array}{l}.012 \\
(.34)\end{array}$ \\
\hline$\Delta$ LnAssets & $\begin{array}{l}.371^{* * *} \\
(6.40)\end{array}$ & $\begin{array}{l}.373^{* * *} \\
(6.39)\end{array}$ & $\begin{array}{l}.371^{* * *} \\
(6.33)\end{array}$ & GoingConcern & $\begin{array}{l}.005 \\
(.07)\end{array}$ & $\begin{array}{l}.011 \\
(.16)\end{array}$ & $\begin{array}{l}.007 \\
(.11)\end{array}$ \\
\hline$\Delta$ LnBusSeg & $\begin{array}{c}-.043 \\
(.83)\end{array}$ & $\begin{array}{c}-.044 \\
(.86)\end{array}$ & $\begin{array}{c}-.044 \\
(.86)\end{array}$ & Big 4 & $\begin{array}{l}-.001 \\
-.04\end{array}$ & $\begin{array}{l}.000 \\
(.01)\end{array}$ & $\begin{array}{l}.000 \\
(.01)\end{array}$ \\
\hline$\Delta \mathrm{LnGeoSeg}$ & $\begin{array}{l}-.034 \\
(.73)\end{array}$ & $\begin{array}{l}-.037 \\
(.78)\end{array}$ & $\begin{array}{l}-.036 \\
(.78)\end{array}$ & CountMW & $\begin{array}{l}-.024^{* *} \\
(2.35)\end{array}$ & $\begin{array}{l}-.025^{* *} \\
(2.36)\end{array}$ & $\begin{array}{l}-.025^{* *} \\
(2.37)\end{array}$ \\
\hline$\Delta \operatorname{RecInv}$ & $\begin{array}{l}-.160 \\
(.58)\end{array}$ & $\begin{array}{l}-.159 \\
(.57)\end{array}$ & $\begin{array}{r}-.159 \\
(.57)\end{array}$ & RepeatMW & $\begin{array}{l}.006 \\
(.22)\end{array}$ & $\begin{array}{l}.006 \\
(.22)\end{array}$ & $(.21)^{.006}$ \\
\hline$\triangle \mathrm{ROA}$ & $\begin{array}{l}-.109 \\
(1.34)\end{array}$ & $\begin{array}{l}-.112 \\
(1.37)\end{array}$ & $\begin{array}{l}-.114 \\
(1.39)\end{array}$ & TaxHaven & $\begin{array}{l}-.015 \\
(.18)\end{array}$ & $\begin{array}{l}-.008 \\
(.09)\end{array}$ & $\begin{array}{r}-.011 \\
(.11)\end{array}$ \\
\hline$\Delta$ Loss & $\begin{array}{c}.049 \\
(1.42)\end{array}$ & $\begin{array}{c}.049 \\
(1.40)\end{array}$ & $\begin{array}{c}.048 \\
(1.39)\end{array}$ & Constant & $\begin{array}{l}.028 \\
(.32)\end{array}$ & $\begin{array}{r}-.007 \\
(.01)\end{array}$ & $\begin{array}{l}.092 \\
(.48)\end{array}$ \\
\hline $\begin{array}{l}\Delta \text { GoingCon- } \\
\text { cern }\end{array}$ & $\begin{array}{l}.014 \\
(.19)\end{array}$ & $\begin{array}{l}.013 \\
(.18)\end{array}$ & $\begin{array}{l}.013 \\
(.18)\end{array}$ & $\begin{array}{l}\text { Industry Fixed } \\
\text { Effects }\end{array}$ & Yes & Yes & Yes \\
\hline$\Delta \mathrm{Big} 4$ & $\begin{array}{l}.353^{* * * *} \\
(5.72)\end{array}$ & $\begin{array}{l}.354^{* * *} \\
(5.72)\end{array}$ & $\begin{array}{l}.354^{* * *} \\
(5.74)\end{array}$ & $\begin{array}{l}\text { Year Fixed } \\
\text { Effects }\end{array}$ & Yes & Yes & Yes \\
\hline LnAssets & $\begin{array}{l}.001 \\
(.15)\end{array}$ & $\begin{array}{l}.001 \\
(.07)\end{array}$ & $\begin{array}{l}.001 \\
(.09)\end{array}$ & $\begin{array}{l}\text { Observations } \\
\text { R-squared }\end{array}$ & $\begin{array}{c}1,155 \\
.20\end{array}$ & $\begin{array}{c}1,155 \\
.20\end{array}$ & $\begin{array}{c}1,155 \\
.20\end{array}$ \\
\hline
\end{tabular}

Notes: this table presents the results of OLS regressions, where the dependent variable is the change in audit fees following a MWICFR. All variables are defined in Appendix A. Tstatistics are reported below the coefficients. ${ }^{* *},{ }^{* *}$, and ${ }^{*}$ denote statistical significance at the $1 \%, 5 \%$, and $10 \%$ levels, respectively.

The results in the last columns of both Tables 5 and 6 show that foreign firms with foreign auditors face less severe audit market consequences, namely a lower likelihood of auditor resignations and lower likelihood of a receiving a going concern report. These results could reflect low audit quality of foreign as compared to U.S.based auditors (Asthana et al., 2015) or a lower liability exposure for foreign auditors compared to the U.S. audit environment (Seetharaman et al., 2002; Cheng et al., 2014).

Having examined the external market's reaction to MWICFR and the auditor's reaction to MWICFR for U.S. compared to foreign cross-listed firms, we now turn to how the firms themselves react to these issues. Table 8 presents the results examining the likelihood of turnover in the two key management positions responsible for financial reporting, the $\mathrm{CFO}$ and $\mathrm{CEO}$. The results provide strong support that foreign firms are significantly less likely than their U.S. counterparts to change their 
CFOs or CEOs after reporting a material weakness. These results are not influenced by the home market regulatory environment or the use of a U.S. or foreign auditor, implying that these factors do not impact the firm-level decision to change top management, consistent with the findings in Johnstone et al. (2011) that firm-level variables are significantly associated with $\mathrm{CEO}$ and $\mathrm{CFO}$ turnover, while external factors, like analyst following and stock exchange listings, are not significantly associated with turnover of these positions.

Table 8

CFO and CEO Change

\begin{tabular}{|c|c|c|c|c|c|c|}
\hline & \multicolumn{3}{|c|}{ Logit(CFO_Change) } & \multicolumn{3}{|c|}{ Logit(CEO_Change) } \\
\hline & $(1)$ & $(2)$ & (3) & (4) & $(5)$ & $(6)$ \\
\hline Foreign & $\begin{array}{c}-16.16^{* * *} \\
(85.65)\end{array}$ & $\begin{array}{c}-15.44^{* * *} \\
(3.93)\end{array}$ & $\begin{array}{c}-13.29^{* * *} \\
(11.83)\end{array}$ & $\begin{array}{c}-15.66^{* * *} \\
(58.52)\end{array}$ & $\begin{array}{l}-6.315 \\
(0.89)\end{array}$ & $\begin{array}{c}-12.82^{* * *} \\
(15.24)\end{array}$ \\
\hline RuleLaw & & $\begin{array}{l}1.784 \\
(0.44)\end{array}$ & $\begin{array}{l}1.392 \\
(0.57)\end{array}$ & & $\begin{array}{l}10.15 \\
(1.36)\end{array}$ & $\begin{array}{l}6.175 \\
(1.42)\end{array}$ \\
\hline ForeignAuditor & & $\begin{array}{r}-0.126 \\
(0.31)\end{array}$ & $\begin{array}{l}-0.037 \\
(0.09)\end{array}$ & & $\begin{array}{c}-1.210^{* *} \\
(1.98)\end{array}$ & $\begin{array}{l}-1.125^{*} \\
(1.76)\end{array}$ \\
\hline Foreign*RuleLaw & & $\begin{array}{l}0.055 \\
(0.01)\end{array}$ & & & $\begin{array}{l}-8.161 \\
(1.04)\end{array}$ & \\
\hline Foreign*ForeignAuditor & & & $\begin{array}{c}-1.206 \\
(0.96)\end{array}$ & & & $\begin{array}{l}-0.344 \\
(0.24)\end{array}$ \\
\hline ROA & $\begin{array}{l}-0.416 \\
(1.30)\end{array}$ & $\begin{array}{l}-0.409 \\
(1.27)\end{array}$ & $\begin{array}{l}-0.415 \\
(1.29)\end{array}$ & $\begin{array}{l}0.385 \\
(0.97)\end{array}$ & $\begin{array}{l}0.414 \\
(1.08)\end{array}$ & $\begin{array}{l}0.413 \\
(1.08)\end{array}$ \\
\hline LnAssets & $\begin{array}{c}-0.088^{*} \\
(1.71)\end{array}$ & $\begin{array}{c}-0.089^{*} \\
(1.73)\end{array}$ & $\begin{array}{c}-0.089^{*} \\
(1.72)\end{array}$ & $\begin{array}{l}0.058 \\
(1.02)\end{array}$ & $\begin{array}{c}0.0492 \\
(0.88)\end{array}$ & $\begin{array}{c}0.0489 \\
(0.87)\end{array}$ \\
\hline Loss & $\begin{array}{c}0.384^{* *} \\
(2.36)\end{array}$ & $\begin{array}{c}0.376^{* *} \\
(2.29)\end{array}$ & $\begin{array}{c}0.373^{* *} \\
(2.27)\end{array}$ & $\begin{array}{c}0.621^{* *} \\
(3.32)\end{array}$ & $\begin{array}{c}0.596^{* * *} \\
(3.18)\end{array}$ & $\begin{array}{c}0.602^{* * *} \\
(3.21)\end{array}$ \\
\hline GoingConcern & $\begin{array}{c}-0.266 \\
(0.72)\end{array}$ & $\begin{array}{c}-0.256 \\
(0.68)\end{array}$ & $\begin{array}{l}-0.280 \\
(0.77)\end{array}$ & $\begin{array}{c}0.755^{* *} \\
(2.10)\end{array}$ & $\begin{array}{c}0.866^{* *} \\
(2.35)\end{array}$ & $\begin{array}{l}0.868^{* *} \\
(2.36)\end{array}$ \\
\hline Big4 & $\begin{array}{l}0.060 \\
(0.35)\end{array}$ & $\begin{array}{l}0.066 \\
(0.38)\end{array}$ & $\begin{array}{l}0.067 \\
(0.39)\end{array}$ & $\begin{array}{l}0.059 \\
(0.30)\end{array}$ & $\begin{array}{l}0.095 \\
(0.47)\end{array}$ & $\begin{array}{l}0.098 \\
(0.49)\end{array}$ \\
\hline CountMW & $\begin{array}{l}0.036 \\
(0.89)\end{array}$ & $\begin{array}{l}0.036 \\
(0.89)\end{array}$ & $\begin{array}{l}0.037 \\
(0.90)\end{array}$ & $\begin{array}{l}0.082^{*} \\
(1.85)\end{array}$ & $\begin{array}{l}0.076^{*} \\
(1.71)\end{array}$ & $\begin{array}{l}0.077^{*} \\
(1.72)\end{array}$ \\
\hline RepeatMW & $\begin{array}{c}0.024 \\
(.16)\end{array}$ & $\begin{array}{c}0.030 \\
(.20)\end{array}$ & $\begin{array}{c}0.028 \\
(.19)\end{array}$ & $\begin{array}{c}-0.092 \\
(.51)\end{array}$ & $\begin{array}{c}-0.050 \\
(.28)\end{array}$ & $\begin{array}{c}-0.058 \\
(.32)\end{array}$ \\
\hline OperatingCF & $\begin{array}{l}.833^{*} \\
(1.65)\end{array}$ & $\begin{array}{c}.814 \\
(1.60)\end{array}$ & $\begin{array}{c}.813 \\
(1.60)\end{array}$ & $\begin{array}{l}-.532 \\
(0.94)\end{array}$ & $\begin{array}{l}-.563 \\
(1.01)\end{array}$ & $\begin{array}{l}-.545 \\
(0.97)\end{array}$ \\
\hline CFO_Change & & & & $\begin{array}{l}.964^{* * *} \\
(5.40)\end{array}$ & $\begin{array}{l}.960^{* * *} \\
(5.40)\end{array}$ & $\begin{array}{l}.959^{* * *} \\
(5.40)\end{array}$ \\
\hline CEO_Change & $\begin{array}{l}.955^{* * *} \\
(5.37)\end{array}$ & $\begin{array}{l}.949^{* * *} \\
(5.34)\end{array}$ & $\begin{array}{l}.949^{* * *} \\
(5.35)\end{array}$ & & & \\
\hline TaxHaven & $\begin{array}{c}14.28^{* * *} \\
(24.25)\end{array}$ & $\begin{array}{c}13.83^{* * *} \\
(21.71)\end{array}$ & $\begin{array}{c}12.56^{* * *} \\
(17.17)\end{array}$ & $\begin{array}{c}13.88^{* * *} \\
(19.83)\end{array}$ & $\begin{array}{l}13.09^{* * *} \\
(15.92)\end{array}$ & $\begin{array}{l}12.61^{* * *} \\
(17.29)\end{array}$ \\
\hline Constant & $\begin{array}{c}-0.982^{* * *} \\
(2.69)\end{array}$ & $\begin{array}{c}-2.604 \\
(0.69)\end{array}$ & $\begin{array}{c}-2.248 \\
(1.00)\end{array}$ & $\begin{array}{c}-2.739^{* * *} \\
(6.45)\end{array}$ & $\begin{array}{c}-11.97^{*} \\
(1.74)\end{array}$ & $\begin{array}{c}-8.331^{* *} \\
(2.09)\end{array}$ \\
\hline Observations & 1,155 & 1,155 & 1,155 & 1,155 & 1,155 & 1,155 \\
\hline Pseudo R-squared & .09 & .09 & .09 & .10 & .10 & .10 \\
\hline
\end{tabular}

Notes: this table presents the results of logit regressions, where the dependent variable measures if the CFO (columns 1-3) or CEO (columns 4-6) changed following a MWICFR. All variables are defined in Appendix A. Z-statistics are reported below the coefficients. ${ }^{* *}$, ${ }^{* *}$, and ${ }^{*}$ denote statistical significance at the $1 \%, 5 \%$, and $10 \%$ levels, respectively. 
Overall, we provide evidence that the aftereffects of MWICFR for foreign crosslisted firms differs from that of U.S. firms. For each area examined, we find different factors that drive this variation. The home market regulatory environment, as proxied by RuleLaw, mitigates the negative repercussions foreign firms face compared to U.S. firms in the equity and debt markets. The use of a foreign auditor (ForeignAuditor) impacts the audit consequences foreign firms face compared to U.S. firms. Lastly, internal changes for companies with internal control issues, captured by $\mathrm{CEO}$ and $\mathrm{CFO}$ turnover, is not influenced by external factors such as the regulatory market or the audit market, but is found to be significantly different for foreign cross-listed firms compared to U.S. firms.

\section{CONCLUSION}

This study observes the consequences of reporting material weaknesses in internal control over financial reporting for cross-listed firms from three different perspectives. We document the response of investors, external auditors, and the firms to these disclosures and compare this response to that faced by U.S. firms reporting MWICFR. We find that foreign cross-listed firms face a significantly more negative stock market reaction and a significant decrease in credit ratings compared to U.S. firms, are less likely to have auditor resignations and more likely to receive a going concern audit opinion, and lastly, are significantly less likely to change their CEOs or CFOs after reporting material weakness issues than U.S. firms.

Further examining these differences, we find that the home market regulatory environment mitigates the negative equity and debt market reactions for foreign firms. We also find that the presence of foreign auditors for foreign firms alleviates audit market consequences, resulting in a lower likelihood of auditor resignations and going concern audit opinions. Lastly, we find that turnover of top management is not impacted by including additional controls for the home market regulatory quality or location of the audit firm.

By comparing U.S. and foreign firms in our analysis, we intersect the literature on cross-listing effects and ICFR consequences. In light of the ongoing debate as to the benefits of SOX internal control mandates, and legislation that reduces the requirement for audit reports on ICFR for certain issuers, this study provides evidence that the reactions to disclosures of MWICFR may differ for domestic and foreign firms.

\section{REFERENCES}

Altamuro, J. M., \& Beatty, A. (2010, February). How does internal control regulation affect financial reporting? Journal of accounting \& Economics, 49(1-2), 58-74.

Ashbaugh-Skaife, H., Collins, D. W., Kinney, W. R. Jr., \& LaFond, R. (2008, January). The effect of SOX internal control deficiencies and their remediation on accrual quality. The Accounting Review, 83(1), 217-250.

Ashbaugh-Skaife, H., Collins, D. W., Kinney, W. R. Jr., \& LaFond, R. (2009, March). The effect of SOX internal control deficiencies on firm risk and cost of equity. Journal of Accounting Research, 47(1), 1-43.

Asthana, S., Raman, K. K., \& Xu, H. (2015, September). US-listed foreign companies' choice of a US-based versus home country-based big $\mathrm{N}$ principal auditor and the effect on audit fees and earnings quality. Accounting Horizons, 29(3), 631-666.

Atilgan, Y., Ghosh, A., Yan, M., \& Zhang, J. (2015, August). Cross-listed bonds, information asymmetry, and conservatism in credit ratings. Journal of Money, Credit \& Banking, 47(5), 897-929. 
Bamber, L. S., Jiang, J., \& Wang, I. Y (2010, July). What's my style? The influence of top managers on voluntary corporate financial disclosure. The Accounting Review, 85(4), 1131-1162.

Beneish, M. D., Billings, M. B., \& Hodder, L. D. (2008, May). Internal control weaknesses and information uncertainty. The Accounting Review, 83(3), 665-703.

Berkman, H., \& Truong, C. (2009, March). Event day 0? After-hours earnings announcements. Journal of Accounting Research, 47(1), 71-103.

Brown, N. C., Pott, C., \& Woempener, A. (2014, January-February). The effect of internal control and risk management regulation on earnings quality: Evidence from Germany. Journal of Accounting \& Public Policy, 33(1), 1-31.

Caban-Garcia, M. T., Figueroa, C. B. R., \& Petruska, K. A. (2017). The impact of culture on internal control weaknesses: Evidence from firms that cross-list in the US. Journal of International Accounting Research, 16(3), 119-145.

Cheng, B., Srinivasan, S., \& Yu, G. (2014). Securities litigation risk for foreign companies listed in the US. Working paper. Retrieved March 12, 2018, from https://papers.ssrn.com/sol3/papers.cfm?abstract_id=2163864.

Cheng, M., Dhaliwal, D., \& Zhang, Y. (2013). Does investment efficiency improve after the disclosure of material weaknesses in internal control over financial reporting? Journal of Accounting \& Economics, 56(1), 1-18.

Doidge, C., Karolyi, G. A., \& Stulz, R. M. (2004, February). Why are foreign firms listed in the U.S. worth more? Journal of Financial Economics, 71(2), 205-238.

Doyle, J. T., Ge, W., \& McVay, S. (2007a, October). Accruals quality and internal control over financial reporting. The Accounting Review, 82(5), 1141-1170.

Doyle, J. T., Ge, W., \& McVay, S. (2007b, September). Determinants of weaknesses in internal control over financial reporting. Journal of Accounting \& Economics, 44(1-2), 193-223.

Dyreng, S. D. \& Lindsey, B. P. (2009, December). Using financial accounting data to examine the effect of foreign operations located in tax havens and other countries on US multinational firms' tax rates. Journal of Accounting Research, 47(5), 1283-1316.

Dyreng, S. D., Hanlon, M., \& Maydew, E. L. (2010, July). The effects of executives on corporate tax avoidance. The Accounting Review, 85(4), 1163-1189.

Ettredge, M., Heintz, J., Li, C., \& Scholz, S. (2011, March). Auditor realignments accompanying implementation of SOX 404 ICFR reporting requirements. Accounting Horizons, 25(1), 17-39.

EY. (2017). An analysis of trends in the US capital markets. Retrieved March 15, 2019 from https://www.ey.com/Publication/vwLUAssets/an-analysis-of-trends-in-the-uscapital-markets/\$FILE/ey-an-analysis-of-trends-in-the-us-capital-markets.pdf.

Feng, M., Li, C., \& McVay, S. E. (2009, December). Internal control and management guidance. Journal of Accounting \& Economics, 48(2/3), 190-209.

Feng, M., Li, C., McVay, S. E., \& Skaife, H. (2015, March). Does ineffective internal control over financial reporting affect a firm's operations? Evidence from firms' inventory management. The Accounting Review, 90(2), 529-557.

Ferguson, L. (2015). Big four audit quality can differ widely-even at the same firm. Retrieved April 10, 2019 from https://www.marketwatch.com/story/big-four-auditquality-can-differ-widely-even-at-the-same-firm-2015-11-17.

Garg, M., Gul, F. A., \& Wickramanayake, J. (2017, July). Evaluating the credibility of voluntary internal controls certification. Journal of International Accounting Research, 16(3), 91-117. Https://doi.org/10.2308/jiar-51856. 
Ge, W. \& McVay, S. E. (2005, September). The disclosure of material weaknesses in internal control after the Sarbanes-Oxley Act. Accounting Horizons, 19(3), 137158.

Goh, B. W., \& Li, D. (2011, May). Internal controls and conditional conservatism. The Accounting Review, 86(3), 975-1005.

Gong, G., Ke, B., \& Yu, Y. (2013, February). Home country investor protection, ownership structure and cross-listed firms' compliance with SOX-mandated internal control deficiency disclosures. Contemporary Accounting Research, 30(4), 1490-1523.

Hail, L., \& Leuz, C. (2009, September). Cost of capital effects and changes in growth expectations around U.S. cross-listings. Journal of Financial Economics, 93(3), 428454.

Hammersley, J. S., Myers, L. A., \& Zhou, J. (2012). The failure to remediate previously disclosed material weaknesses in internal controls. Auditing: A Journal of Practice \& Theory, 31(2), 73-111.

Hammersley, J. S., Myers, L. A., \& Shakespeare, C. (2008). Market reactions to the disclosure of internal control weaknesses and to the characteristics of those weaknesses under section 302 of the Sarbanes-Oxley act of 2002. Review of Accounting Studies, 13(1), 141-165.

Harp, N. L. \& Barnes, B. G. (2018, January). Internal control weakness and acquisition performance. The Accounting Review, 93(1), 235-258. Https://doi.org/ $10.2308 /$ accr-51780.

Hogan, C. E., \& Wilkins, M. S. (2008). Evidence on the audit risk model: do auditors increase audit fees in the presence of internal control deficiencies? Contemporary Accounting Research, 25(1), 219-242.

Hoitash, U., Hoitash, R., \& Bedard, J. C. (2008, May). Internal control quality and audit pricing under the Sarbanes-Oxley Act. Auditing: A Journal of Practice \& Theory 27(1), 105-126.

Hoitash, U., Hoitash, R., \& Bedard, J. C. (2009, May). Corporate governance and internal control over financial reporting: A comparison of regulatory regimes. The Accounting Review, 84(3), 839-867.

Hope, O. -K., Kang, T., \& Kim, J. W. (2013, June). Voluntary disclosure practices by foreign firms cross-listed in the United States. Journal of Contemporary Accounting \& Economics, 9(1), 50-66.

Johnstone, K., Li, C., \& Rupley, K. H. (2011, Spring). Changes in corporate governance associated with the revelation of internal control material weaknesses and their subsequent remediation. Contemporary Accounting Research, 28(1), 331383.

Kanagaretnam, K., Lobo, G. J., Ma, C., \& Zhou, J. (2016, January). National culture and internal control material weaknesses around the world. Journal of Accounting, Auditing \& Finance, 31(1), 28-50.

Karolyi, A. G. (2006, March). The world of cross-listings and cross-listings of the world: Challenging conventional wisdom. Review of Finance, 10(1), 99-152.

Kaufmann, D., \& Kraay, A. (2016). Governance indicators for 1996-2016. Washington, D.C.: World Bank Policy Research.

Kizirian, T. G., Mayhew, B. W., \& Sneathen, L. D. Jr. (2005, November). The impact of management integrity on audit planning and evidence. Auditing: A Journal of Practice \& Theory, 24(2), 49-67. 
Lang, M., Raedy, J. S., \& Wilson, W. (2006, October). Earnings management and cross listing: Are reconciled earnings comparable to US earnings? Journal of Accounting \& Economics, 42(1-2), 255-283.

Lang, M., Raedy, J. S., \& Yetman, M. H. (2003, February). How representative are firms that are cross-listed in the United States? An analysis of accounting quality. Journal of Accounting Research, 41(2), 363-386.

Lawrence, A., Minutti-Meza, M., \& Vyas, D. (2018). Is operational control risk informative of financial reporting deficiencies? Auditing: A Journal of Practice \& Theory, 37(1), 139-165.

Leuz, C. (2003, February). Discussion of ADRs, analysts, and accuracy: Does crosslisting in the United States improve a firm's information environment and increase market value? Journal of Accounting Research, 41(2), 347-362.

Leuz, C., Nanda, D., \& Wysocki, P. D. (2003, September). Earnings management and investor protection: An international comparison. Journal of Financial Economics, 69(3), 505-527.

Li, C., Sun, L., \& Ettredge, M. (2010, May). Financial executive qualifications, financial executive turnover, and adverse SOX 404 opinions. Journal of Accounting \& Economics, 50(1), 93-110.

Li, X. (2014, August). The Sarbanes-oxley act and cross-listed foreign private issuers. Journal of Accounting \& Economics, 58(1), 21-40.

Ogneva, M., Subramanyam, K. R., \& Raghunandan, K. (2007). Internal control weakness and cost of equity: Evidence from SOX section 404 disclosures. The Accounting Review, 82(5), 1255-1297.

Raghunandan, K., \& Rama, D. V. (2006, May). SOX Section 404 material weakness disclosures and audit fees. Auditing: A Journal of Practice \& Theory, 25(1), 99-114. Https://doi.org/10.2308/aud.2006.25.1.99.

Reese Jr., W. A., \& Weisbach, M. S. (2002, October). Protection of minority shareholder interests, cross-listings in the United States, and subsequent equity offerings. Journal of Financial Economics, 66(1), 65-104.

Roychowdhury, S., Shroff, N., \& Verdi, R. S. (2019). The effects of financial reporting and disclosure on corporate investment: A review. Journal of Accounting \& Economics, 68(2-3), 101246. Https://doi.org/10.1016/j.jacceco.2019.101246.

Securities \& Exchange Commission (SEC). (2002, August 29). Certification of disclosure in companies' quarterly and annual reports (release nos. 34-46079, file nos. S7-21-02). Washington, D.C.: U.S. Securities and Exchange Commission.

Securities \& Exchange Commission (SEC). (2003, June 5). Management's reports on internal control over financial reporting and certification of disclosure in exchange act periodic reports (release nos. 33-8238, 34-47986, ic-26068, file nos. S7-40-02; S7-06-03). Washington, D.C.: U.S. Securities and Exchange Commission.

Securities \& Exchange Commission (SEC). (2010). Internal control over financial reporting in exchange act period reports of non-accelerated filers (release nos. 33-9142; 34-62914). Washington, D.C.: U.S. Securities and Exchange Commission.

Securities \& Exchange Commission (SEC). (2013). Accessing the U.S. capital markets--a brief overview for foreign private issuers. Washington, D.C.: U.S. Securities and Exchange Commission. Retrieved March 5, 2019 from https://www.sec.gov/divisions/corpfin/internatl/foreign-private-issuersoverview.shtml\#IIIB1. 
Seetharaman, A., Gul, F. A., \& Lynn, S. G. (2002, February). Litigation risk and audit fees: Evidence from UK firms cross-listed on US markets. Journal of Accounting \& Economics, 33(1), 91-115.

Skaife, H. A., Veenman, D., \& Wangerin, D. (2013). Internal control over financial reporting and managerial rent extraction: Evidence from the profitability of insider trading. Journal of Accounting \& Economics, 55(1), 91-110.

Srinivasan, S., Wahid, A. S., \& Yu, G. (2015, May). Admitting mistakes: Home country effect on the reliability of restatement reporting. The Accounting Review, 90(3), 1201-1240.

Wilford, A. L. (2016, May-June). Internal control reporting and accounting standards: A cross-country comparison. Journal of Accounting \& Public Policy, 35(3), 276-302.

Zhang, J. (2018). Public governance and corporate fraud: Evidence from the recent anti-corruption campaign in China. Journal of Business Ethics, 148(2), 375-396.

\section{Appendix A}

Variable Definitions

\begin{tabular}{|c|c|}
\hline Variable & Definitions \\
\hline $\operatorname{Big} 4$ & 1 if the auditor is a Big 4 auditor, 0 otherwise \\
\hline Book-to-market & Book value per share divided by yearend market price per share \\
\hline CAR & $\begin{array}{l}\text { Cumulative abnormal return (CAR) for each firm-year observation in the } \\
\text { two-day window }(-1,0) \text { around the issuance of the auditor's report } \\
\text { containing the material weakness }\end{array}$ \\
\hline CEO_Change & 1 if there is a CEO change between year $t$ and $t+1,0$ otherwise \\
\hline CFO_Change & 1 if there is a CFO change between year $t$ and $t+1,0$ otherwise \\
\hline CountMW & Number of material weaknesses reported \\
\hline Foreign & 1 if the entity is incorporated outside the US, 0 otherwise \\
\hline ForeignAuditor & 1 if the audit firm is located in a foreign jurisdiction, 0 otherwise \\
\hline Going_Concern & 1 if a company received a going-concern audit opinion, 0 otherwise \\
\hline Leverage & Ratio of long term debt to total assets \\
\hline LnAssets & Natural log of total assets \\
\hline LnAuditFee & Natural log of audit fees \\
\hline LnBusSeg & Natural log of number of business segments \\
\hline LnGeoSeg & Natural log of number of geographic segments \\
\hline Loss & 1 if earnings before extraordinary items is negative, 0 otherwise \\
\hline OperatingCF & Cash flows from operations scaled by total assets \\
\hline RecInv & Ratio of receivables and inventory to total assets \\
\hline RepeatMW & $\begin{array}{l}1 \text { if the firm has reported multiple years of MWICFR during the sample } \\
\text { period }\end{array}$ \\
\hline Resigned & 1 if a firm's auditor resigned, 0 otherwise \\
\hline Resigned & $\begin{array}{l}1 \text { for auditor resignations per the Audit Analytics Auditor Change } \\
\text { database, and } 0 \text { otherwise }\end{array}$ \\
\hline ROA & Earnings before extraordinary items divided by total assets \\
\hline RuleLaw & $\begin{array}{l}\text { Percentile ranking of the rule of law measure from Kaufman and Kray } \\
\text { (2016) divided by } 100\end{array}$ \\
\hline TaxHaven & 1 if the firm is incorporated in a jurisdiction denoted as a tax haven \\
\hline$\Delta \mathrm{Big} 4$ & $\begin{array}{l}\text { Change in Big } 4 \text { defined as } 1 \text { if the auditor is a Big- } 4 \text { auditor, } 0 \text { otherwise, } \\
\text { from year t to } t+1\end{array}$ \\
\hline$\Delta$ GoingConcern & $\begin{array}{l}\text { Change in Going_Concern defined as } 1 \text { if a company received a going- } \\
\text { concern audit opinion, } 0 \text { otherwise, from year } t \text { to } t+1\end{array}$ \\
\hline$\Delta$ InterestRate & $\begin{array}{l}\text { Change in interest expense divided by the average of short- and long-term } \\
\text { debt from year } t \text { to } t+1\end{array}$ \\
\hline$\Delta$ Leverage & Change in the ratio of long term debt to total assets from year $t$ to $t+1$ \\
\hline
\end{tabular}


To be continued from Appendix A.

\begin{tabular}{|c|c|}
\hline Variable & Definitions \\
\hline$\Delta$ LnAssets & Change in the natural log of total assets from year $t$ to $t+1$ \\
\hline$\Delta$ LnAuditFees & Change in the natural log of audit fees from year $t$ to $t+1$ \\
\hline$\Delta \mathrm{LnBusSeg}$ & $\begin{array}{l}\text { Change in the natural log of number of business segments from year } t \text { to } \\
t+1\end{array}$ \\
\hline$\Delta \mathrm{LnGeoSeg}$ & $\begin{array}{l}\text { Change in the natural log of number of geographic segments from year } t \\
\text { to } t+1\end{array}$ \\
\hline$\Delta$ Loss & $\begin{array}{l}\text { Change in Loss, defined as } 1 \text { if earnings before extaordinary items is } \\
\text { negative, } 0 \text { otherwise, from year t to } t+1\end{array}$ \\
\hline$\triangle$ OperatingCF & $\begin{array}{l}\text { Change in cash flows from operations scaled by total assets from year } t \text { to } \\
t+1\end{array}$ \\
\hline$\Delta$ Rating & $\begin{array}{l}\text { Change in the Standard \& Poor's }(\mathrm{S} \& \mathrm{P}) \text { long-term domestic issuer senior } \\
\text { credit rating from Compustat from the year } t \text { to } t+1 \text {, where the letter } \\
\text { credit rating is converted to a numeric range from } 1 \text { denoting the highest } \\
\text { AAA and } 17 \text { denoting a rating of CCC }+ \text { or lower }\end{array}$ \\
\hline$\Delta$ RecInv & $\begin{array}{l}\text { Change in the ratio of receivables and inventory to total assets from year } t \\
\text { to } t+1\end{array}$ \\
\hline$\triangle \mathrm{ROA}$ & $\begin{array}{l}\text { change in earnings before extraordinary items divided by total assets from } \\
\text { year t to } t+1\end{array}$ \\
\hline
\end{tabular}

